\title{
Negative regulation of proneural gene activity: hairy is a direct transcriptional repressor of achaete
}

\author{
Mark Van Doren, ${ }^{1}$ Adina M. Bailey, Joan Esnayra, Kekoa Ede, and James W. Posakony² \\ Department of Biology and Center for Molecular Genetics, University of California San Diego, \\ La Jolla, California 92093-0322 USA
}

\begin{abstract}
hairy $(h)$ acts as a negative regulator in both embryonic segmentation and adult peripheral nervous system (PNS) development in Drosophila. Here, we demonstrate that $h$, a basic-helix-loop-helix (bHLH) protein, is a sequence-specific DNA-binding protein and transcriptional repressor. We identify the proneural gene achaete (ac) as a direct downstream target of $h$ regulation in vivo. Mutation of a single, evolutionarily conserved, high-affinity $h$ binding site in the upstream region of $a c$ results in the appearance of ectopic sensory organs in adult flies, in a pattern that strongly resembles the phenotype of $h$ mutants. This indicates that direct repression of $a c$ by $h$ plays an essential role in pattern formation in the PNS. Our results demonstrate that HLH proteins negatively regulate $a c$ transcription by at least two distinct mechanisms.
\end{abstract}

[Key Words: Drosophila; neurogenesis; peripheral nervous system; transcriptional repression; helix-loop-helix; negative regulation]

Received August 2, 1994; revised version accepted September 21, 1994.

The sensory organs that comprise the adult peripheral nervous system (PNS) of Drosophila offer an excellent system for the study of pattern formation during development. These sensory organs, which include the mechanosensory bristles, are distributed over the body surface of the fly in a highly reproducible pattern. Each sensory organ arises from a single precursor cell, the sensory organ precursor (SOP) (Hartenstein and Posakony 1989). SOPs are determined in a precise spatial and temporal pattern within the developing imaginal discs and histoblast nests (Bang et al. 1991; Huang et al. 1991), the tissues that will give rise to the epidermis of the adult. The establishment of the SOP cell fate has been studied extensively at the genetic and molecular levels and can be divided into two steps. In the first step, the competence to become a SOP is conferred on groups of cells called proneural clusters by the localized activities of the proneural genes achaete $(a c)$, scute ( $s c)$, and daughterless (da) (Cubas et al. 1991; Skeath and Carroll 1991), which encode basic-helix-loop-helix (bHLH) transcriptional activators (Villares and Cabrera 1987; Caudy et al. 1988; Cronmiller et al. 1988; Cabrera and Alonso 1991; Van Doren et al. 1992|. Whereas $d a$ is expressed ubiquitously (Cronmiller and Cummings 1993), $a c$ and sc are expressed in a spatially restricted manner (Cubas et al. 1991; Skeath and Carroll 1991). Mutation of genes such

\footnotetext{
${ }^{1}$ Present address: Whitehead Institute, Nine Cambridge Center, Cambridge, Massachusetts 02142 USA.

${ }^{2}$ Corresponding author.
}

as hairy $(h)$, extramacrochaetae (emc), and pannier (pnr) leads to ectopic ac-sc expression and ectopic sensory organs (Mohr 1918, as cited in Lindsley and Zimm 1992; Botas et al. 1982; Cubas et al. 1991; Skeath and Carroll 1991; Cubas and Modolell 1992; Van Doren et al. 1992; Martinez et al. 1993; Orenic et al. 1993; Ramain et al. 1993), indicating that negative regulation plays an important role in proneural cluster patterning. In the second step of the process, proneural potential is further restricted to a single cell within the proneural cluster, the SOP. This involves local inhibitory cell-cell interactions (lateral inhibition) mediated by the neurogenic group of genes, which includes Notch $(N)$, Delta $(D l)$, Suppressor of Hairless [Su(H)], and the Enhancer of split complex [E(spl)-C] (Knust et al. 1987; Hartenstein and Posakony 1990; Heitzler and Simpson 1991, 1993; Schweisguth and Posakony 1992; Parks and Muskavitch 1993). Thus, negative regulation is essential in this second step of SOP specification as well.

$h$ was first identified by the ectopic bristle phenotype conferred by loss-of-function mutations (Mohr 1918, as cited in Lindsley and Zimm 1992) and was later shown to function also as a pair-rule gene during embryonic segmentation (Nüsslein-Volhard and Wieschaus 1980). The ectopic sensory organs observed in $h$ mutants are dependent on $a c$ gene activity (Sturtevant 1970; Moscoso del Prado and García-Bellido 1984), and ac is expressed ectopically in these mutants (Skeath and Carroll 1991; Orenic et al. 1993|. These findings indicate that $h$ acts as a negative regulator of $a c$ during adult PNS development, 
either directly or indirectly. However, a molecular basis for $h$ function in either sensory organ development or embryonic segmentation has not been determined.

The h protein (Rushlow et al. 1989) is a member of a structurally distinct group of bHLH proteins, first identified in Drosophila, that also includes the products of seven genes of the E/spl)-C (Delidakis and Artavanis-Tsakonas 1992; Knust et al. 1992). We refer to these genes collectively as the $\mathrm{h} / \mathrm{E} / \mathrm{spl} /$ family. Homologous genes have been identified in mammals (Sasai et al. 1992; Feder et al. 1993|, and there is evidence that at least one $\mathrm{h} / \mathrm{E}$ (spl) family member in the rat may also act as a negative regulator in nervous system development (Ishibashi et al. 1994|, suggesting that this family has been conserved functionally as well as structurally during evolution. $\mathrm{h} / \mathrm{E} / \mathrm{spl}$ ) family members share a characteristic basic domain adjacent to their HLH domain, which suggested that these proteins might be capable of binding DNA /Van Doren et al. 1991; Wainwright and IshHorowicz 1992). In vitro DNA-binding activity has been observed for some family members, including the $\mathrm{E} / \mathrm{s}$ pl)m8 protein (Tietze et al. 1992) and the rat HES-1, HES2, and HES-5 proteins (Akazawa et al. 1992; Sasai et al. 1992; Ishibashi et al. 1993|. Moreover, HES-1, -2, and -5 are capable of acting as transcriptional repressors in tissue culture cotransfection assays (Akazawa et al. 1992; Sasai et al. 1992; Ishibashi et al. 1993; Takebayashi et al. 1994), suggesting that the $\mathrm{h} / \mathrm{E}(\mathrm{spl})$ family functions differently from other well-studied bHLH proteins, which act as transcriptional activators. Recent evidence indicates that both rat (Takebayashi et al. 1994) and Drosophila (Kramatschek and Campos-Ortega 1994) h/E(spl) proteins function in negative autoregulation.

In this report we demonstrate that $\mathrm{h}$ is a sequencespecific DNA-binding protein and binding site-dependent transcriptional repressor. We also provide in vivo evidence that the proneural gene $a c$ is a direct downstream target of $h$ repression. These results establish a molecular mechanism of action for $h$ in regulating nervous system development and are directly relevant to the functions of other $\mathrm{h} / \mathrm{E} / \mathrm{spl}$ ) family members from Drosophila as well as other species.

\section{Results \\ $h$ binds to a specific site in the upstream region of achaete}

Genetic evidence indicating that $h$ is a regulator of $a c$, as well as structural features of the $h$ protein suggesting a possible DNA-binding activity, prompted us to look for specific h-binding sites in the $a c$ upstream region (Fig. 1A). As shown in Figure 1B, a single 110-bp restriction fragment from the $5^{\prime}$-flanking sequence of $a c$ is preferentially precipitated by a purified protein consisting of glutathione $S$-transferase (GST) fused to a truncated form of $h$ (GST-htr). This activity is not an artifact of deleting part of the $h$ protein or fusing $h$ to GST, as we have found that a full-length GST-h fusion protein binds with similar specific activity and that $\mathrm{h}$ synthesized in vitro in
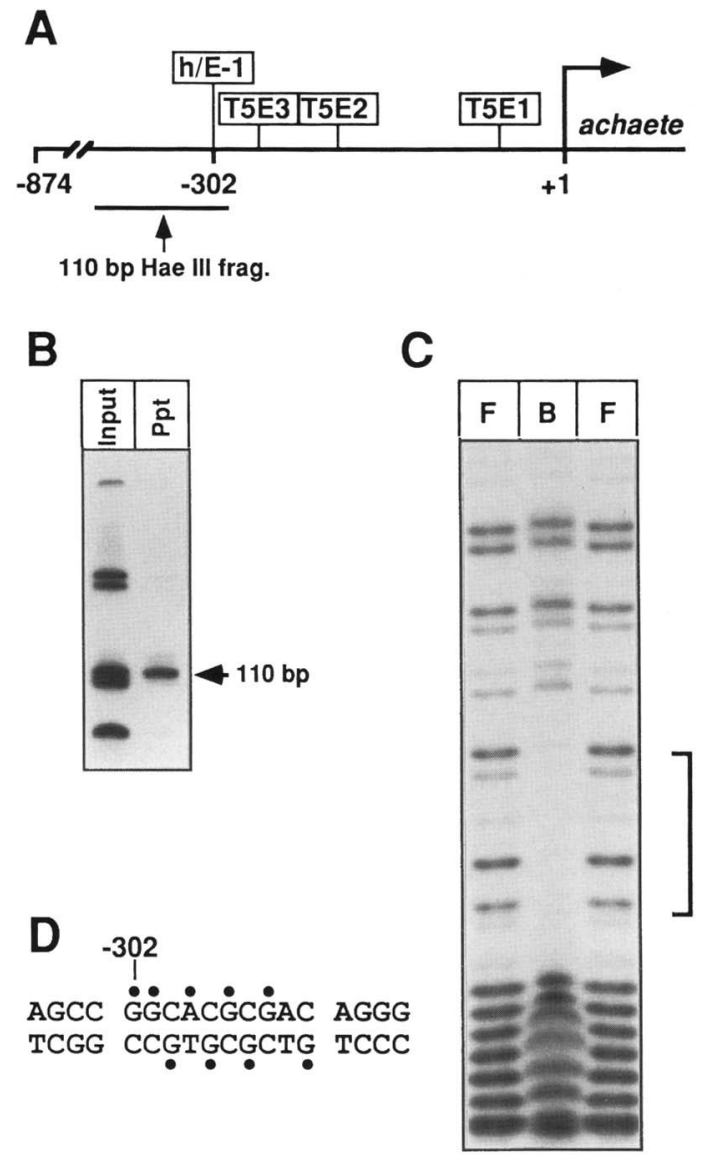

Figure 1. Identification of a h-binding site in the ac upstream region. (A) Diagram of the ac region immediately $5^{\prime}$ to the transcription start site. Indicated are the three E-box binding sites (T5E1-3) that mediate ac-sc-dependent auto- and cross-activation of $a c$, the 110-bp HaeIII restriction fragment that interacts specifically with $h$, and the newly identified $h / E$ /spl)-binding site (h/E-1). Numbers are in base pairs relative to the start of transcription $(+1) .(B)$ Precipitation of HaeIII restriction fragments from $0.9 \mathrm{~kb}$ of ac upstream sequence by GST-htr protein. (Input) Untreated radiolabeled HaelII fragments $10 \%$ of the amount precipitated in Ppt lane) separated on a nondenaturing polyacrylamide gel. (Ppt) The same HaeIII fragments after incubation with GST-htr protein and precipitation with glutathione-Sepharose beads. A single 110 -bp fragment is precipitated by GST-htr. $(C \mid$ Methylation protection assay of thrombincleaved htr binding to the 110-bp HaeIII fragment. (F) Cleavage pattern of DMS-treated free DNA loutside lanes); (B) cleavage pattern of DNA bound by htr (middle lane). The brackets indicate the region protected from methylation by htr. The labeled DNA strand corresponds to the upper strand in $D$. (D) Summary of methylation protection results from both DNA strands in the vicinity of the h/E-1 site. (O) Nucleotides protected from methylation by DMS.

wheat germ translation lysates also binds efficiently (not shown; see Fig. 2B,C). Dimethyl-sulfate (DMS) methylation protection assays identify within this fragment a single 10 -bp protected sequence, GGCACGCGAC, beginning at position -302 upstream of the ac transcription start site (Fig. 1A,C-D). We refer to this site as the 
A

\begin{tabular}{|c|c|c|c|c|c|c|c|c|c|c|c|c|c|c|}
\hline Position: & & & 1 & 2 & 3 & 4 & 5 & 6 & 7 & 8 & 9 & 10 & & \\
\hline$\% \mathbf{G}:$ & 35 & 26 & 56 & 58 & 0 & 0 & 0 & 93 & 7 & 71 & 18 & 24 & 11 & 31 \\
\hline$\%$ A: & 20 & 26 & 12 & 19 & 0 & 81 & 0 & 3 & 0 & 0 & 36 & 5 & 47 & 15 \\
\hline$\% \mathrm{T:}$ & 15 & 17 & 16 & 8 & 4 & 8 & 0 & 3 & 10 & 17 & 5 & 10 & 21 & 38 \\
\hline$\% \mathrm{C}:$ & 30 & 30 & 16 & 15 & 96 & 12 & 100 & 0 & 83 & 12 & 41 & 62 & 21 & 15 \\
\hline Consensus: & & & $\mathbf{g}$ & $\mathbf{g}$ & C & $\mathbf{A}$ & C & G & C & $\mathbf{G}$ & $a / c$ & c & & \\
\hline E Box: & & & & & C & $\mathbf{A}$ & $\mathbf{N}$ & $\mathbf{N}$ & $\mathbf{T}$ & $\mathbf{G}$ & & & & \\
\hline D. melanogaster: & & & $\mathbf{G}$ & $\mathbf{G}$ & C & $\mathbf{A}$ & C & $\mathbf{G}$ & $\mathbf{C}$ & $\mathbf{G}$ & $\mathbf{A}$ & C & & \\
\hline D. virlilis: & & & $\mathbf{G}$ & $\mathbf{G}$ & C & $\mathbf{A}$ & C & $\mathbf{G}$ & C & $\mathbf{G}$ & $\mathbf{A}$ & C & & \\
\hline
\end{tabular}

Figure 2. DNA-binding characteristics of the $\mathrm{h}$ protein. $(A)$ Consensus GST-htrbinding site determined by random binding site selection. The frequency with which a given nucleotide was observed at each positition in the aligned sequences is shown. Percentages are rounded to the nearest integer, so totals do not always equal $100 \%$. Twenty-nine independent clones were sequenced, but the $n$ for each position varies, because whenever nonrandom portions of the random-1 oligonucleotide overlapped the aligned sequence, these base pairs were excluded from the analysis. The consensus site shown was derived by selecting any position where a nucleotide was present at $>50 \%$ frequency (lowercase letters) or $>70 \%$ frequency (uppercase letters). Also shown are the consensus E-box sequence and the $a c$ h/E-1 sequences from both $D$. melanogaster and $D$. virilis. $(B)$ EMSA with fulllength GST-h protein ( $\sim 40$ fmoles) and the D. melanogaster ac h/E-1 site oligonu-

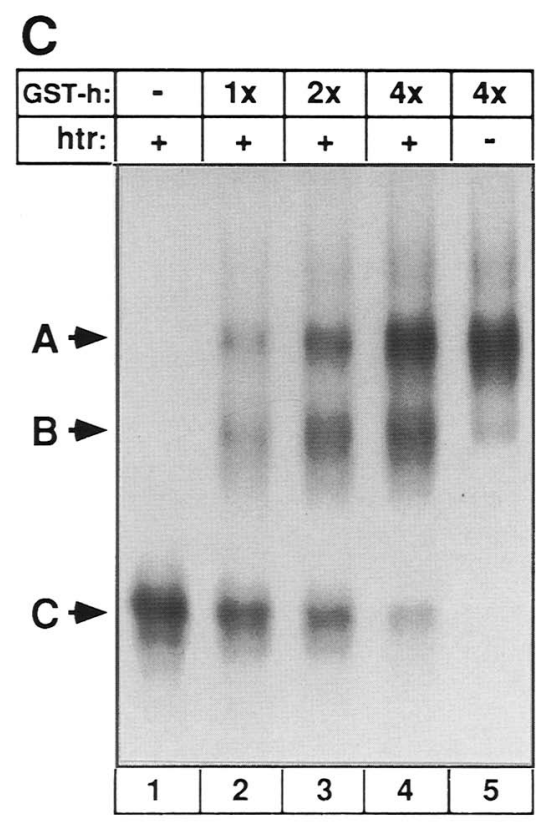

B

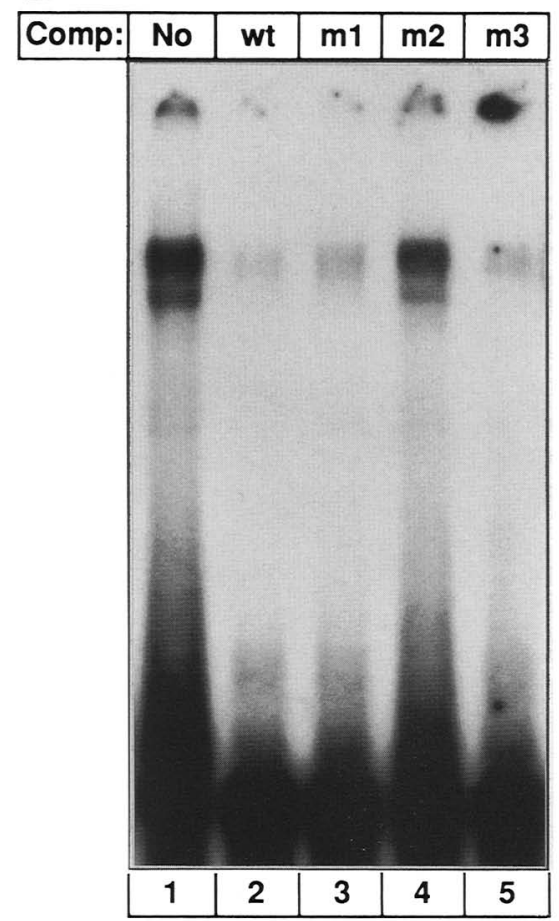

cleotide (40 fmoles) as a probe. (Lane 1) No specific competitor; (lanes 2-5) various specific competitor oligonucleotides, as indicated, in a 20 -fold molar excess over the probe. Sequence differences between wild-type $(\mathrm{wt})$ and mutant $(\mathrm{m} 1, \mathrm{~m} 2, \mathrm{~m} 3)$ competitors are indicated. $(C)$ EMSA combining different forms of $h$ protein [full-length GST-h fusion (GST-h) and truncated, in vitro-translated $h$ (htr)] as an assay for h multimerization. Lanes 1 and 5, respectively, show the pattern of shifted complexes observed with htr or GST-h alone. The predominant complex formed with each protein is labeled (A for GST-h and C for htr). Lanes 2-4 show combinations of both proteins in the same binding reaction. As more GST- $h$ is included with a constant amount of htr, a single new binding complex is formed (complex B) with an electrophoretic mobility intermediate between the major complexes observed with either GST-h or htr alone.

$a c \mathrm{~h} / \mathrm{E}-\mathrm{l}$ site, because of its ability to bind both $\mathrm{h}$ and at least one bHLH protein encoded by the E(spl)-C (see below).

We determined an optimal consensus sequence for GST-htr binding using a random binding site selection protocol (S. Erdman and K. Burtis, pers. comm.). A GSThtr protein column was used to fractionate a doublestranded random oligonucleotide pool in which each oligonucleotide contained $14 \mathrm{bp}$ of random sequence at its center. After two rounds of selection, GST-htr exhibited clear binding preferences over a 10-bp region, with sequences in the center of the region being selected for more strongly than those at either end (Fig. 2A). Interestingly, the $a c \mathrm{~h} / \mathrm{E}-1$ site matches this consensus at 10 of 10 positions (Fig. 2A). Moreover, the upstream region of the $a c$ gene from a distantly related species, Drosophila virilis, also contains a 10 of 10 match to the $h$ consensus (Fig. 2A). This 10 of 10 match is part of a 15-bp stretch of sequence that is identical between the $a c$ genes of $D$. melanogaster and $D$. virilis, though the two upstream regions are, for the most part, highly diverged (not shown).

The random selection experiments suggest that the peripheral nucleotides of the $\mathrm{h}$-binding site contribute to the specificity of the interaction but not as much as nucleotides in the center of the site (Fig. 2A). We tested this directly with a full-length GST-h fusion protein in an electrophoretic mobility shift assay (EMSA), with a double-stranded oligonucleotide ac h/E-1 probe. GST-h binds efficiently to the $a c \mathrm{~h} / \mathrm{E}-1$ site in the absence of specific competitor (Fig. 2B, lane 1), but a 20 -fold molar excess of unlabeled wild-type oligonucleotide effectively competes for this binding activity (lane 2). When the G in position 1 of the $a c \mathrm{~h} / \mathrm{E}-1$ site is changed to a $\mathrm{T} / \mathrm{m} 1$, Fig. 2B), we find that the ability of the mutant oligonucleotide to act as a competitor is slightly but reproduc- 
ibly diminished from that of the wild-type oligonucleotide (lane 3 ), whereas mutation of the $C$ at position 3 of the $a c \mathrm{~h} / \mathrm{E}-1$ site $(\mathrm{m} 2$, Fig. $2 \mathrm{~B})$ has a much more drastic effect (lane 4). These results are consistent with the random selection data (Fig. 2A). Changing the $a c$ h/E-1 site to fit the E-box (CANNTG) consensus (position 7 $\mathrm{C} \rightarrow \mathrm{T}$; m3, Fig. $2 \mathrm{~B}$ ) yields a sequence that is still an excellent competitor for GST-h binding (lane 5). However, when this E-box version of the h-binding site is compared with the wild-type $a c \mathrm{~h} / \mathrm{E}-1$ site in binding to and eluting from a GST-htr column, we find that the E-box version $(\mathrm{m} 3)$ elutes at a lower salt concentration than does the wild-type site (data not shown).

Finally, we investigated whether, by analogy to certain other bHLH proteins (Murre et al. 1989), h binds DNA as a homo-oligomer. Figure $2 \mathrm{C}$ shows the results of an EMSA experiment combining full-length GST-h with a truncated $h$ protein synthesized by in vitro translation in a wheat germ lysate (htr). As expected from their relative molecular masses $(64 \mathrm{kD}$ for GST-h and $12 \mathrm{kD}$ for $\mathrm{htr}$ ), these two forms of $h$ individually yield protein-DNA complexes of very different electrophoretic mobilities (lanes 1 and 5, complexes A and C). As the amount of GST- $h$ is increased in the presence of a constant amount of htr, a single complex of intermediate mobility appears (complex B) and increases in abundance at the expense of complex $C$ (lanes 2-4). This indicates that htr and GST-h can both be present in the same oligomeric, probably dimeric, DNA-binding complex.

\section{$h$ acts as a transcriptional repressor}

We used cotransfection assays in Drosophila Schneider (S2) cells to address what effect on gene expression, if any, $h$ exhibits when bound to DNA. As illustrated in Figure $3 \mathrm{~A}$, we constructed a reporter gene containing four tandem copies of the $a c \mathrm{~h} / \mathrm{E}-1$ site immediately upstream of an alcohol dehydrogenase (ADH) minimal promoter directing expression of a bacterial chloramphenicol acetyltransferase (CAT)-coding sequence. We also generated an identical reporter construct in which each of the four $a c \mathrm{~h} / \mathrm{E}-1$ sites contains a l-bp mutation that severely reduces $h$ binding in vitro $(\mathrm{m} 2$, Fig. $2 B)$. As shown in Figure 3B, full-length h clearly acts to repress expression from the ADH minimal promoter, reproducibly showing a 5- to 10-fold reduction in CAT activity. Furthermore, repression by $h$ in this assay strictly requires the integrity of the $a c \mathrm{~h} / \mathrm{E}-1$ sites, as demonstrated by the elimination of h's effect on reporter gene expression when these sites have been altered by a single base pair. This experiment establishes that a short oligonucleotide containing the $a c \mathrm{~h} / \mathrm{E}-\mathrm{l}$ site can confer h-dependent transcriptional repression on a heterologous promoter.

\section{Mutation of the ac $h / E-1$ site results in a $\mathrm{h}$ mutant} phenotype in vivo

Because the $a c \mathrm{~h} / \mathrm{E}-\mathrm{l}$ site is an optimal h-binding site in vitro and is conserved in distantly related species of

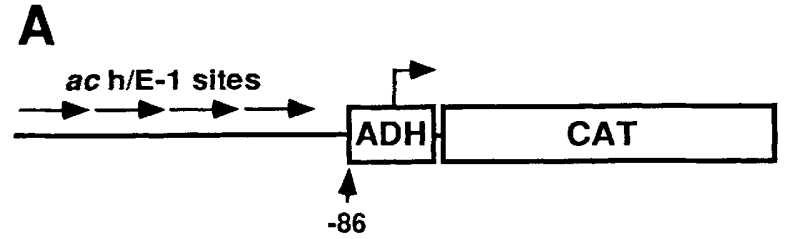

B

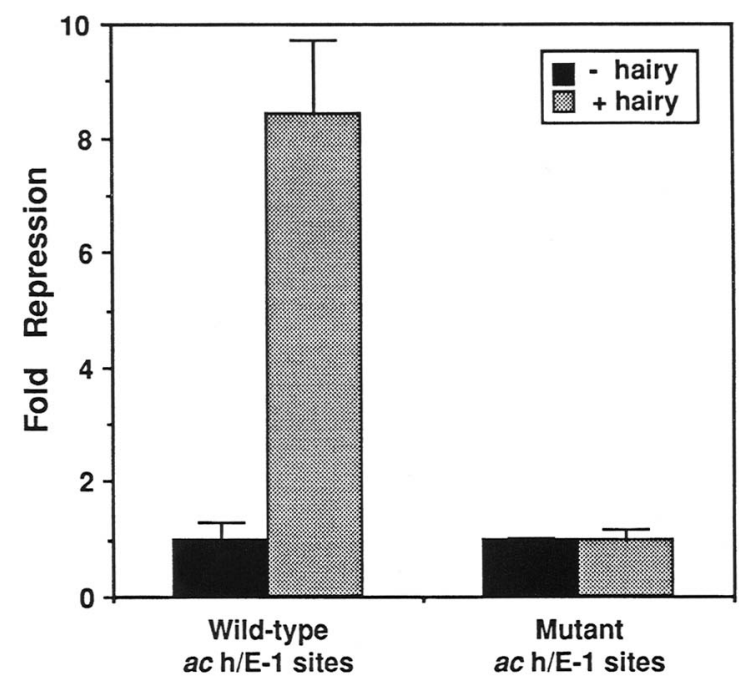

Figure 3. Binding site-dependent transcriptional repression by h. (A) Diagram of the reporter construct used in cotransfection assays. $a c \mathrm{~h} / \mathrm{E}-1$ sites upstream of the $\mathrm{ADH}$ minimal promoter are either wild-type in sequence or mutated at a single base pair. Changes in $\mathrm{ADH}$ promoter activity are assayed by measurement of levels of CAT enzyme activity. $(B)$ Effects of h on expression from the wild-type or mutant $a c$ h/E-l ADH-CAT construct. Experiments indicated as + hairy included an expression construct that expresses h from the Drosophila actin $5 \mathrm{C}$ promoter. Control experiments indicated as - hairy included the parental expression vector without insert. Fold repression was calculated relative to the - hairy control. Results shown are an average of five independent experiments.

Drosophila, we were interested in investigating the importance of this site for the regulation of $a c$ by $\mathrm{h}$ in vivo.

Male flies carrying the $s \mathrm{c}^{10-1}$ mutation, which inactivates both $a c$ and $s c$, completely lack mechanosensory bristles on the head and thorax. We have shown previously that a $2.2-\mathrm{kb}$ genomic DNA fragment containing the $a c$ transcription unit, as well as $0.9 \mathrm{~kb}$ of 5 -flanking sequence (Fig. 1A), is capable of providing partial ac function in transgenic flies that carry this mutation /referred to hereafter as $\left.a c^{-} s c^{-}\right)$. Thus, a wild-type $a c$ transgene can rescue numerous mechanosensory bristles in normal positions on the body surface of $a c^{-} s c^{-}$males (Van Doren et al. 1992).

Figure 4 demonstrates that like the endogenous $a c$ gene, the activity of the wild-type $a c$ transgene is subject to negative regulation by $h$ and that this regulation is independent of endogenous $a c-s c$ function. A represen- 


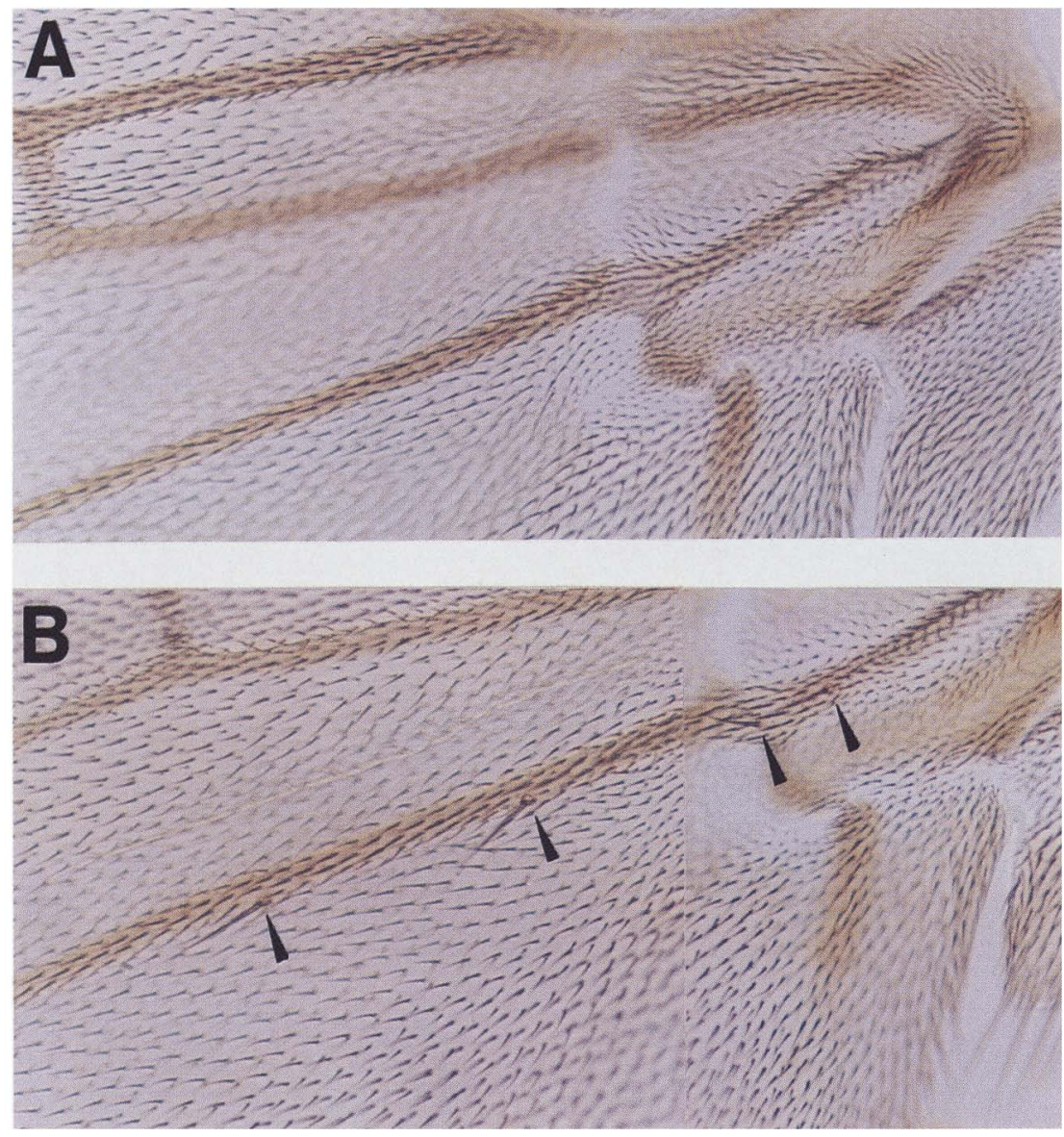

Figure 4. A wild-type $a c$ transgene is subject to regulation by $h$. Mounted wing blade preparations are shown, focusing on the proximal portion of wing vein L5. $(A)$ Wild-type $a c$ transgene insertion C3-2 in an $a c^{-} s c^{-}$genetic background (genotype $s c^{10-1} w^{1118} / Y$; C3-2). No ectopic bristles are observed. (B) Wild-type ac transgene insertion C3-2 in an $a c^{-} s c^{-} h^{-}$genetic background /genotype $s c^{10-1} w^{1118} / Y$; C3-2 $s e h^{1}$ ). Note the four ectopic bristles along wing vein L5 (arrowheads). tative wild-type transgene insertion produces no ectopic wing bristles in $a c^{-} s c^{-}$males $\{n=20$ wing blades; Fig. 4A). However, the same transgene in a genetic background that is also mutant for $h\left(a c^{-} s c^{-} h^{-}\right.$; Fig. 4B) gives a clear ectopic bristle phenotype (mean $=6.8 \pm 3.1$ ectopic bristles per wing blade, $n=4)$.

We then constructed a mutant $a c$ transgene that is identical to the wild-type transgene except for mutation of $3 \mathrm{bp}$ within the h/E-1 site (core hexamer CACGCG changed to CCCTCT), which severely reduces or eliminates $\mathrm{h}$ binding to this site (not shown). We compared the bristle phenotypes of 6 independent transformant lines carrying the wild-type $a c$ transgene with the phenotypes of 10 independent lines carrying the mutant transgene. As shown in Figure 5A and summarized in Table 1, four of the six insertions of the wild-type $a c$ transgene produce no ectopic wing bristles in wild-type females, although they can restore many normal microchaete bristles to $a c^{-} s c^{-}$males (Van Doren et al. 1992). In the other two lines, a single ectopic bristle is observed on wing vein $\mathrm{L} 5$ in a small fraction of individuals (Table 1). In contrast, 9 of the 10 insertions of the $\mathrm{h} / \mathrm{E}-1$ mutant ac transgene show an ectopic bristle phenotype in wildtype females (Fig. 5C,D; Table 1). The single h/E-1 mutant ac transgene insertion that does not exhibit an ectopic bristle phenotype in wild-type flies (line I4-1) also has a severely reduced ability to rescue normal microchaetes in the $\mathrm{ac}^{-} \mathrm{sc}^{-}$background (not shown), indicating that it is located in a chromosomal position that strongly represses its activity. The other nine h/E-1 mutant $a c$ transgenic lines display a range of phenotypes, with the weakest (Fig. 5C; Table 1, line I3-4) consisting of one to four bristles on wing vein L5 in $75 \%$ of the animals $(n=20)$. This effect, however, is still clearly stronger than the strongest phenotype observed among the lines carrying the wild-type $a c$ transgene (Table 1, cf. lines C5-1 and I3-4). The stronger $\mathrm{h} / \mathrm{E}-1$ mutant $a c$ transgene phenotypes observed (Table 1) consist of numerous ectopic bristles on the wing (Fig. 5D) and pleura (Fig. 5I), ectopic campaniform sensilla on the wing blades, and one or a few ectopic bristles on the scutellum and legs. Strikingly, these phenotypes are also observed in nontransgenic $h$ mutant flies (Fig. 5, cf. C and D to B; cf. I to $\mathrm{H}$; see also Table 1 ), though, as expected for a transgene that supplies only partial ac activity, none of the transgenic lines exhibit a complete $h$ mutant phenotype.

Because of the known auto- and cross-regulatory activities of $a c$ and $s c$ in the imaginal disc (Martinez and Modolell 1991; Van Doren et al. 1991, 1992; Martinez et al. 1993), we anticipated that the ac transgenes would be subject to activation by the endogenous $a c$ and $s c$ genes, and vice versa. This prompted us to test the independent 
Van Doren et al.
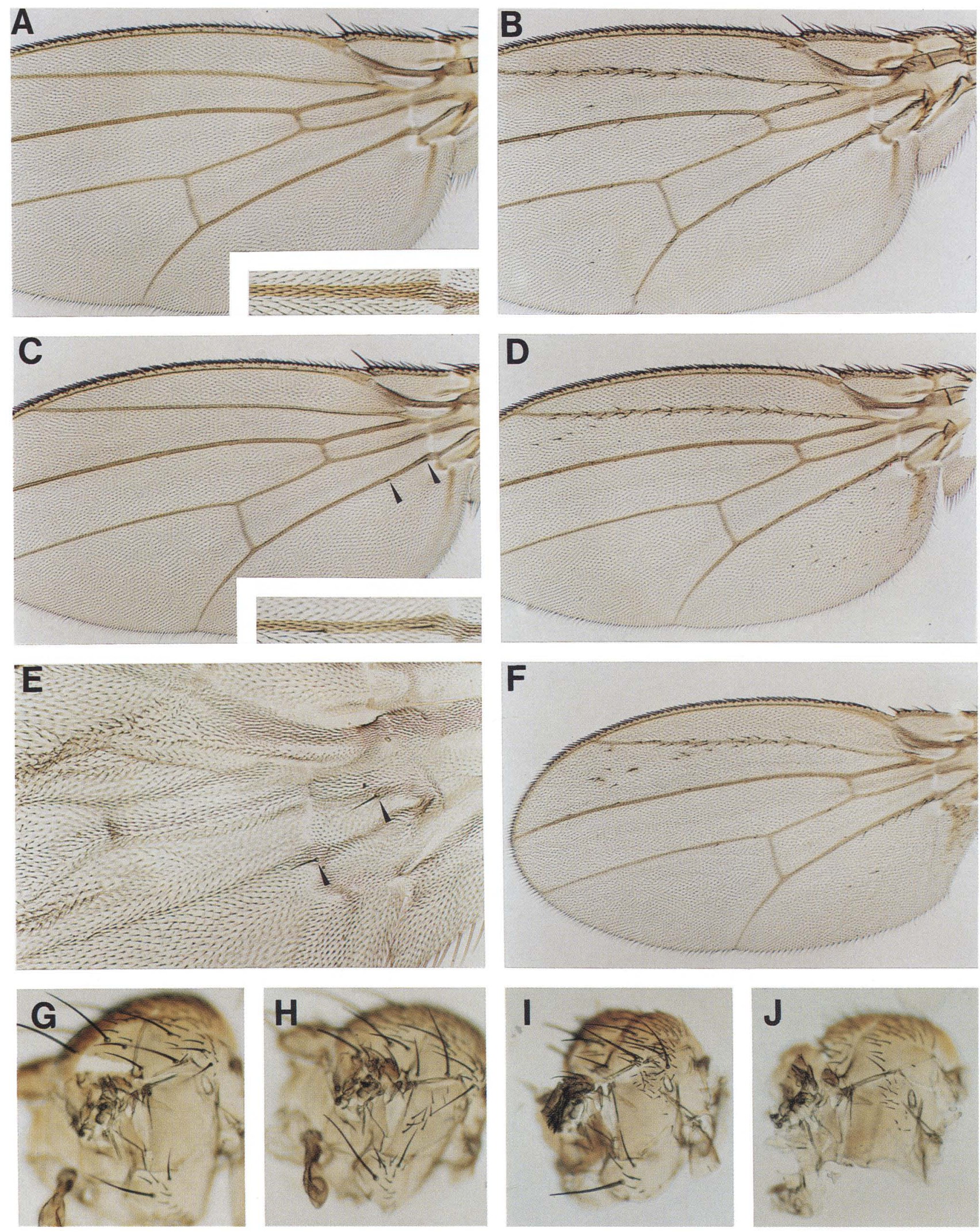

Figure 5. (See facing page for legend.) 
Table 1. Phenotypes of wild-type and $h / E-1$ mutant ac transgenic lines

\begin{tabular}{|c|c|c|c|c|c|c|c|c|}
\hline \multirow[b]{2}{*}{ Transgene } & \multirow{2}{*}{$\begin{array}{l}\text { Line or } \\
\text { mutation }\end{array}$} & \multirow[b]{2}{*}{$n$} & \multirow{2}{*}{$\begin{array}{l}\text { Number } \\
\text { of wing } \\
\text { bristles }^{\mathrm{a}}\end{array}$} & \multicolumn{5}{|c|}{ Phenotype $^{\mathrm{b}}$} \\
\hline & & & & 1 & 2 & 3 & 4 & 5 \\
\hline \multirow{6}{*}{$\begin{array}{l}\text { Wild-type } \\
a c \\
\text { transgene }\end{array}$} & C3-1 & 20 & 0 & & & & & \\
\hline & C4-1 & 20 & 0 & & & & & \\
\hline & C6-2 & 20 & 0 & & & & & \\
\hline & $C 7-4$ & 20 & 0 & & & & & \\
\hline & C3-2 & 25 & 0.16 & $\mathrm{X}$ & & & & \\
\hline & C5-1 & 25 & 0.24 & $\mathrm{X}$ & & & & \\
\hline \multirow{10}{*}{$\begin{array}{l}\mathrm{h} / \mathrm{E}-1 \text { mutant } \\
\quad \text { ac } \\
\text { transgene }\end{array}$} & I4- $1^{c}$ & 15 & $0^{\mathrm{c}}$ & & & & & \\
\hline & I3-4 & 20 & 1.3 & $\mathrm{X}$ & $\mathrm{X}$ & & & \\
\hline & I7-1 & 15 & 1.5 & $\mathrm{X}$ & $\mathrm{X}$ & & & \\
\hline & I6-3 & 25 & 1.8 & $\mathrm{X}$ & $\mathrm{X}$ & & & \\
\hline & I7-2 & 10 & 2.2 & $\mathrm{X}$ & $\mathrm{X}$ & & & \\
\hline & I4- 2 & 10 & 4.6 & & $\mathrm{X}$ & $\mathrm{X}$ & & \\
\hline & I1-1 & 10 & 7.3 & & $\mathrm{X}$ & $\mathrm{X}$ & $\mathrm{X}$ & \\
\hline & I5-1 & 5 & 40 & & $\mathrm{X}$ & $\mathrm{X}$ & $\mathrm{X}$ & $\mathrm{X}$ \\
\hline & I3-2 & 5 & 47 & & $\mathrm{X}$ & $\mathrm{X}$ & $\mathrm{X}$ & $\mathrm{X}$ \\
\hline & $16-2$ & 5 & 72 & & $\mathrm{X}$ & $\mathrm{X}$ & $\mathrm{X}$ & \\
\hline None & $h^{1}$ & 5 & 90 & & $\mathrm{X}$ & $\mathrm{X}$ & $\mathrm{X}$ & $\mathrm{X}$ \\
\hline
\end{tabular}

${ }^{a}$ Mean number of ectopic nonmargin bristles per wing in females homozygous for each insertion or for the $h^{1}$ mutation. The mean numbers of ectopic bristles observed in the $h / E-1$ mutant $a c$ transgenic lines are significantly different from the mean numbers of bristles observed in the wild-type $a c$ transgenic lines (Mann-Whitney $U$ test; $P=0.0042$ ).

'Females from each line were scored for the following phenotypes: (1) Single ectopic bristle only on wing vein L5; (2) multiple ectopic bristles on wing vein L5; (3) ectopic bristles on other nonmargin regions of the wing; (4) ectopic bristles on the pleura; $(5)$ ectopic bristles on the scutellum.

${ }^{c}$ Line I4-1 is also extremely weak in rescuing wild-type bristles in a $s c^{10-1}$ genetic background, indicating that the transgene is inserted in a chromosomal position that represses its activity.

activity of the $\mathrm{h} / \mathrm{E}-1$ mutant $a c$ transgene insertions by introducing them into a genetic background lacking endogenous $a c-s c$ function. Besides rescuing many normal microchaete bristles, three of three independent insertions of the mutant transgene still produce ectopic bristhes in $a c^{-} s c^{-}$flies (Fig. 5E,F), although some reduction in the total number of ectopic bristles is observed. Thus, the ability of the mutant transgene to promote bristle development in ectopic locations does not require the activity of the endogenous $a c$ and $s c$ genes.

In summary, a similar in vivo phenotype is obtained either by mutation of the cis-regulatory site in $a c$ to which $\mathrm{h}$ binds in vitro or by mutation of the gene encoding the $h$ trans-regulator.

\section{The $E($ spl)m 7 protein can repress transcription through the ac $h / E-1$ site}

Genetic evidence that the E(spl)-C is required for negative regulation of $a c$ expression during lateral inhibition (Skeath and Carroll 1992), along with the strong sequence similarities in the basic regions of $h$ and the $\mathrm{E}$ (spl) bHLH proteins, suggested that $\mathrm{E}(\mathrm{spl}) \mathrm{bHLH}$ proteins might interact directly with regulatory sequences in the $a c$ gene, specifically the $\mathrm{h} / \mathrm{E}-1$ site. We found that a GST-E(spl/m7 fusion protein, containing the first 127 amino acids of $\mathrm{E}(\mathrm{spl}) \mathrm{m} 7$ (GST-m7tr), binds to the ac h/E-1 site (Fig. 6A, lane 1) with a specific activity similar to that of GST-h (not shown). Moreover, the sequence specificity of GST-m7tr mimics that of GST- $h$ in a competition assay, as shown by the very similar response of GST-m $7 \mathrm{tr}$ binding to single base pair changes in the $a c$ h/E-1 site (cf. Fig. 2B, lanes 2-5 with Fig. 6A, lanes 2-5). Thus, $a c \mathrm{~h} / \mathrm{E}-1$ appears to be a specific binding site for the $\mathrm{E} / \mathrm{spl} / \mathrm{m} 7$ protein in vitro.

By use of the cotransfection assay described above (see Fig. $3 \mathrm{~A})$, we tested the ability of $E(\mathrm{spl} / \mathrm{m} 7$ to act as a transcriptional repressor through interaction with the $\mathrm{h} / \mathrm{E}-1$ site from ac. As shown in Figure 6B, full-length $\mathrm{E} / \mathrm{spl} / \mathrm{m} 7$ inhibits the activity of the ADH minimal promoter by $\sim 10$-fold when wild-type h/E-1 sites are present upstream, whereas little or no repression is observed when these sites are mutated at a single position (m2 of Fig. 2B; see Fig. 6A, lane 4). We conclude that $\mathrm{E} / \mathrm{spl} \mid \mathrm{m} 7 \mathrm{can}$ function as a DNA-binding protein and transcriptional repressor and that, as with $\mathrm{h}$, the $a c \mathrm{~h} / \mathrm{E}-1$ site can confer $E / \mathrm{spl} / \mathrm{m} 7$-dependent repression on a heterologous promoter.

\section{Discussion}

The Drosophila gene $h$ encodes a bHLH protein that

Figure 5. Mutation of the $a c \mathrm{~h} / \mathrm{E}-1$ site leads to the appearance of ectopic sensory organs. $(A)$ Wing blade of a $w^{1118}$ female homozygous for the wild-type $a c$ transgene (line C3-2). The majority of wing blades of this genotype have no ectopic bristles, even on the proximal region of wing vein $L 5$ (inset). $(B)$ Wing blade of a homozygous $h^{1}$ female. Note the ectopic bristles along all longitudinal wing veins and in some intervein regions. $(C)$ Wing blade of a $w^{1118}$ female homozygous for an insertion of the h/E- 1 mutant ac transgene that gives a weak effect (line I3-4). Note the ectopic bristles on the proximal region of wing vein L5 (arrowheads and inset). (D) Wing blade of a $w^{1118}$ female homozygous for an insertion of the h/E-1 mutant ac transgene that gives a strong effect (line I6-2). Note the numerous ectopic bristles along wing veins $\mathrm{L} 2, \mathrm{~L} 3$, and $\mathrm{L} 5$, as well as in some intervein regions. ( $E-F)$ Wing blades of $a c^{-} s c^{-}$males homozygous for h/E-1 mutant ac transgene insertions. (E) I3-4 (genotype $s c^{10-1} \mathrm{~W}^{1118} / \mathrm{Y} ; \mathrm{I3}-4$ ); (F) I6-2 (genotype $s c^{10-1} \mathrm{~W}^{1118} / \mathrm{Y}^{1}$; I6-2). Ectopic bristles (indicated by arrowheads in $E$ ) are still observed with the h/E-1 mutant $a c$ transgene in an $a c^{-} s c^{-}$genetic background. $|G-I|$ Lateral view of adult male thoraces, showing the pleural region. Dorsal is at the top; anterior is to the right. (G) Wild-type $\left(w^{1118} / Y\right)$. No bristles appear on the pleura of these animals. $(H) h^{1}$ homozygous male. Note the ectopic microchaete bristles on the pluera. $\{I) \mathrm{w}^{1118} / \mathrm{Y}$; I6-2. In the stronger h/E-1 mutant $a c$ transgenic lines, ectopic bristles are observed on the pleura. $(J) \mathrm{sc}^{10-1} \mathrm{w}^{1118} / \mathrm{Y}$; I6-2. Ectopic bristles are still observed on the pleura in an $\mathrm{ac}^{-} \mathrm{sc}^{-}$background. Note the missing macrochaetae and reduced numbers of microchaetae resulting from the loss of endogenous $a c$ and $s c$ activity. 

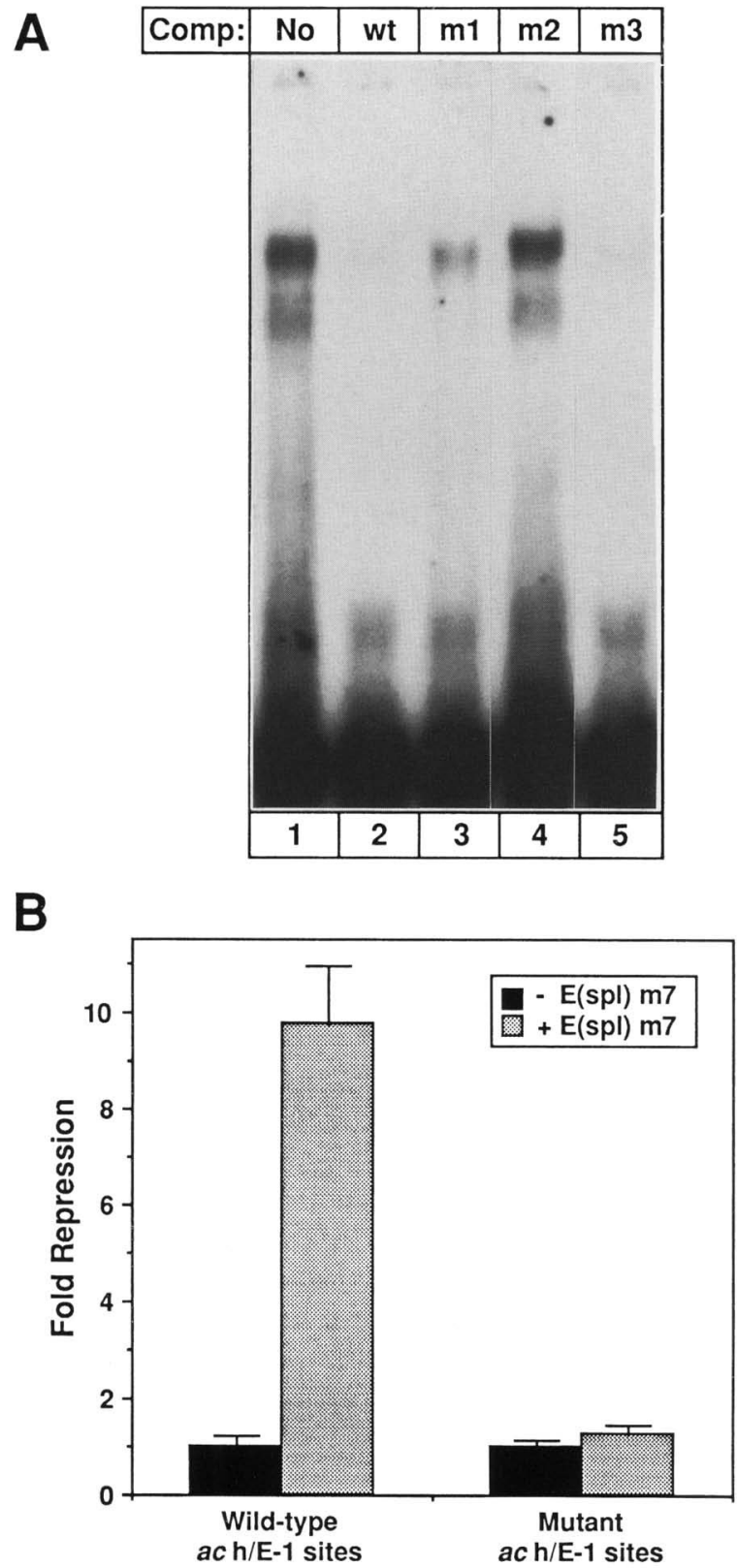

Figure 6. E(spl $/ \mathrm{m} 7$ can bind to and act as a transcriptional repressor through the $a c \mathrm{~h} / \mathrm{E}-1$ sequence. (A) EMSA with GST$\mathrm{m} 7 \mathrm{tr}$ protein ( 40 fmoles) with the $a c \mathrm{~h} / \mathrm{E}-1$ site oligonucleotide (40 fmoles) as a probe. (Lane 1) No specific competitor; (lanes 2-5) specific competitor oligonucleotides, as indicated, at a 20-fold molar excess over the probe. Sequence differences between wild-type $(\mathrm{wt})$ and mutant $(\mathrm{m} 1, \mathrm{~m} 2, \mathrm{~m} 3)$ competitors are as shown in Fig. 2B. $(B)$ Cotransfection assays measuring the effects of $\mathrm{E} / \mathrm{spl} / \mathrm{m} 7$ on expression of the $a c \mathrm{~h} / \mathrm{E}-1 \mathrm{ADH}-\mathrm{CAT}$ reporter constructs diagramed in Fig. 3A. Experiments indicated as $+\mathrm{E}(\mathrm{spl} / \mathrm{m} 7$ included an expression construct that expresses E(spl)m7 from the Drosophila actin 5C promoter. Control experiments indicated as $-E(\mathrm{spl}) \mathrm{m} 7$ included the parental expression vector without insert. Fold repression was calculated relative to the $-E(\mathrm{spl}) \mathrm{m} 7$ control. Results shown are the average of four independent experiments. functions as a negative regulator in both embryonic segmentation and adult PNS development. In this report we show that $h$ is a sequence-specific DNA-binding protein and transcriptional repressor, and we identify the proneural gene $a c$ as a direct downstream target of $h$ regulation. In combination with previous findings concerning the action of emc, these results demonstrate that HLH proteins utilize at least two distinct mechanisms to negatively regulate $a c$ transcription and thus the pattern of adult sensory organs.

\section{$h$ is a sequence-specific DNA-binding protein}

We have shown that purified $h$ fusion proteins exhibit sequence-specific DNA-binding activity in vitro and can recognize a 10-bp sequence in the upstream region of the ac gene, the $a c \mathrm{~h} / \mathrm{E}-1$ site. Determination of a consensus $\mathrm{h}$-binding site by random oligonucleotide selection indicates that $a c h / E-1$ is an optimal site for $h$ binding. Several characteristics of the DNA-binding activity of $h$ are worthy of note. The first is that the amino-terminal 109 amino acids of $h$ (of 337 in the full-length protein) are sufficient to mediate sequence-specific DNA binding. This truncated form of $h$ includes only $\sim 50$ amino acids in addition to the complete bHLH domain and lacks other conserved domains of the $\mathrm{h} / \mathrm{E} / \mathrm{spl})$ family of proteins, such as the two postulated helical regions that lie carboxy-terminal to the bHLH sequence (Knust et al. 1992), and the extreme carboxy-terminal Trp-Arg-ProTrp (WRPW) motif (Klämbt et al. 1989; Rushlow et al. 1989; Delidakis and Artavanis-Tsakonas 1992; Knust et al. 1992). Thus, these regions are not required for DNA binding by $h$. Second, both the random binding site selection experiments (Fig. 2A) and the DNA-binding competition assays (Fig. $2 B$ ) indicate a strong preference by $h$ for specific nucleotides in the core of its binding site (especially the hexamer CACGCG), as well as weaker selectivity in the flanking nucleotides. The stringent selection for CG at the center of the h-binding site is consistent with the presence of an arginine residue at amino acid 44 in the basic region of the protein. An arginine residue in the analogous position in other bHLH or bHLH/ZIP proteins that bind sites with a CG center has been shown to be critical for recognition of these bases (Dang et al. 1992; Ferre-D'Amare et al. 1993). Third, the optimal h-binding site is not a typical E-box (CANNTG; Fig. 2A), whereas the binding sites of almost all bHLH proteins besides those in the $\mathrm{h} / \mathrm{E}$ (spl) family fit this consensus. We have shown that $h$ binds well to an $E$-box version of the $a c \mathrm{~h} / \mathrm{E}-1$ site (GGCACGTGAC; Fig. 2B), though this complex is not as salt resistant as $h$ complexes with $a c h / E-1$. In addition, the $h$ consensus site is related to, but does not match, the $\mathrm{N}$-box sequence (CACNAG), first identified in the upstream region of the $E(s p l) m 8$ gene (Tietze et al. 1992). $\mathrm{N}$ box-containing sequences have been shown to be in vitro binding sites for the E(spl)m8, HES-1, HES-2, and HES-5 proteins (Akazawa et al.1992; Sasai et al 1992; Tietze et al. 1992; Ishibashi et al. 1993), though it has not been determined whether these are optimal binding sites for any of these 
proteins. We find that $\mathrm{h}$ can bind to the $\mathrm{N}$-box sequence from $E(s p l) m 8$ but more weakly than to the $a c \mathrm{~h} / \mathrm{E}-1$ site (not shown). Finally, we note that although we have analyzed the DNA-binding properties of $\mathrm{h}$ alone homooligomeric complexes/ in this study, it is possible that $h$ may also interact with other proteins in hetero-oligomeric DNA-binding complexes. In either case, our data indicate that, at least in part, h's mechanism of action involves sequence-specific DNA binding.

\section{$h$ and $E($ spl)m 7 are transcriptional repressors}

We have shown here that the $\mathrm{h}$ and $\mathrm{E} / \mathrm{spl} / \mathrm{m} 7$ proteins can act as binding site-dependent transcriptional repressors through the same $a c \mathrm{~h} / \mathrm{E}-1$ sequence. It is significant that an oligonucleotide containing the $\mathrm{h} / \mathrm{E}-\mathrm{l}$ site is sufficient to confer transcriptional repression by $\mathrm{h}$ and $\mathrm{E} / \mathrm{spl} / \mathrm{m} 7$ on a heterologous promoter. This indicates that the activity of these proteins as repressors does not depend on the specific context of the $a c$ promoter. For example, $a c$ is subject in vivo to auto- and cross-activation by proneural bHLH protein complexes that bind to three E-box sequences in the $a c$ promoter (Martinez and Modolell 1991; Skeath and Carroll 1991; Van Doren et al. 1991, 1992; Martinez et al. 1993), and one possible model for $h$ regulation of $a c$ is that $\mathrm{h}$ specifically interferes with this activation. However, our data indicate that $h$ and $E / s-$ $\mathrm{pl} / \mathrm{m} 7 \mathrm{can}$ act as repressors independently of the function of bHLH activators.

In addition to their activity as binding site-dependent transcriptional repressors, the rat HES- 1 and HES- 5 proteins have been reported to antagonize the function of bHLH activator proteins by forming inactive heterooligomeric complexes with them (Akazawa et al. 1992; Sasai et al. 1992; Takebayashi et al. 1994). Thus far we have not observed that $h$ interferes with the DNA-binding activity of da/ac-sc protein complexes in vitro /Van Doren et al. 1991) or with their ability to act as transcriptional activators in cotransfection assays (M. Van Doren, unpubl.). Nevertheless, it remains possible that $h$ may have regulatory functions in vivo that do not involve interacting with DNA.

Genetic data indicate that $h$ plays an important role in embryonic segmentation, in part by negatively regulating the expression of fushi tarazu (ftz) (Carroll and Scott 1986; Howard and Ingham 1986; Ish-Horowicz and Pinchin 1987). The product of the deadpan (dpn) gene is very closely related to $h$ (Bier et al. 1992) and acts as a negative regulator in sex determination in the early fly embryo (Younger-Shepherd et al. 1992). Our finding that $\mathrm{h}$ acts as a DNA-binding transcriptional repressor in adult sensory organ development suggests that the same molecular mechanism may contribute to $h$ and/or dpn function in these other developmental processes.

The functional evidence to date is consistent with the generalization that both the fly and mammalian members of the h/E(spl) family of bHLH proteins act as transcriptional repressors, either in negative auto-regulation (Kramatschek and Campos-Ortega 1994; Takebayashi et al. 1994) or in repression of downstream genes (this pa- per). In contrast, the regulatory activities that have been described so far for other DNA-binding bHLH proteins (not including bHLH/ZIP proteins) generally involve transcriptional activation. Thus, activation and repression appear to be functions characteristic of structurally distinct subgroups of bHLH transcriptional regulators.

\section{ac is a direct downstream target of h repression}

The observations reported here strongly support the conclusion that $\mathrm{h}$, or a complex including $\mathrm{h}$, functions as a direct transcriptional repressor of $a c$ through the $a c$ $\mathrm{h} / \mathrm{E}-1$ site in vivo (Fig. 7A) and that such regulation plays an essential role in the patterning of adult sensory organs in the fly. Ohsako et al. (this issue) have independently come to a similar conclusion.

The identification of a proneural gene as a direct downstream target of regulation by a $\mathrm{h} / \mathrm{E} / \mathrm{spl})$ family member may suggest at least one general function for these proteins in both vertebrate and invertebrate neurogenesis. For example, the HES-1 protein has been implicated as a negative regulator of nervous system development in the rat (Ishibashi et al. 1994); downstream targets of repression by HES-1 or related proteins may include genes that are directly involved in promoting the neural cell fate.

We believe it is significant that the $\mathrm{E} / \mathrm{spl} / \mathrm{m} 7$ protein
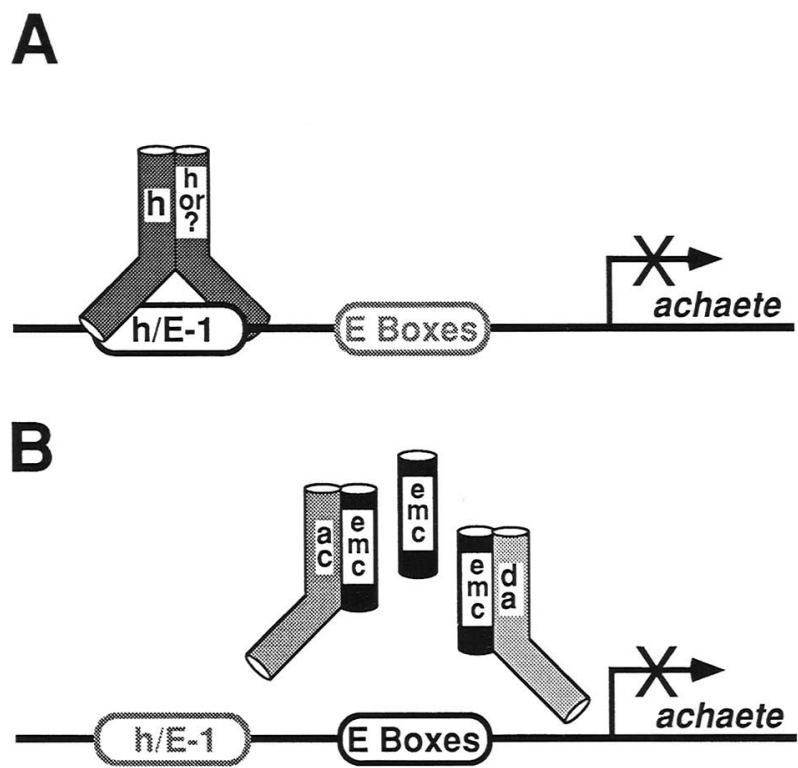

Figure 7. $\mathrm{h}$ and emc exhibit distinct mechanisms for negative regulation of $a c$ expression. (A) Model for regulation of $a c$ expression by $h . h$, in either a homo-oligomeric complex or a hetero-oligomeric complex with an unknown factor, binds to the $\mathrm{h} / \mathrm{E}-1$ site, and acts to repress ac transcription. (B) Model for regulation of $a c$ expression by emc. $a c$ is subject to direct autoand cross-activation, most likely by $\mathrm{ac} / \mathrm{da}$ and $\mathrm{sc} / \mathrm{da}$ (not shown/ protein complexes, acting through E-box binding sites upstream of $a c$. By forming complexes with these proteins that are inactive for DNA binding, emc inhibits their function as transcriptional activators of $a c$. 
can bind to the $a c \mathrm{~h} / \mathrm{E}-1$ site with a sequence specificity and specific activity similar to that of $h$ and can repress transcription through this site (Fig. 6; M. Van Doren, unpubl.). The $\mathrm{E} / \mathrm{spl} \mid-\mathrm{C}$ is required for the process of lateral inhibition in the proneural clusters, which acts to restrict proneural potential to the SOP. During determination of the SOP, proneural gene (including ac) expression is elevated in this cell and down-regulated in the remaining cells of the cluster (Cubas et al. 1991; Skeath and Carroll 1991), in a manner requiring neurogenic gene [including E(spl)-C; Skeath and Carroll 1992] function. Our results raise the possibility that one or more of the $\mathrm{E}$ (spl) bHLH proteins act as direct transcriptional repressors of $a c$ during lateral inhibition. In this view, $\mathrm{h}$ acts as a global regulator in the imaginal disc to help restrict $a c$ expression to the proneural clusters, whereas $E(\mathrm{spl})$ bHLH proteins might act as local regulators to inhibit the expression of $a c$, and possibly other targets, in those cells of the proneural cluster that are prevented from assuming the SOP fate. Such an activity of the E[spl) genes in the proneural clusters may depend on the lateral inhibitory signal. It is clear, however, that singularization of the SOP does not occur solely through transcriptional regulation of proneural gene expression, since individual, well-spaced bristles are produced when proneural genes are expressed under the control of heterologous promoters that are not likely to be regulated by lateral inhibition (Rodriguez et al. 1990; Hinz et al. 1994). Thus, it is possible that $\mathrm{E}(\mathrm{spl}) \mathrm{bHLH}$ proteins might be direct repressors of $a c$ even though we do not observe a neurogenic bristle tufting phenotype in flies carrrying the $a c$ $\mathrm{h} / \mathrm{E}-1$ mutant transgene. It has been shown recently that $E(s p l) m 7$ expression in the wing imaginal disc is under the direct control of the ac and sc bHLH activators (Singson et al. 1994). This suggests that a transcriptional feedback loop may exist in which ac first directly activates $E(s p l) m 7$ expression throughout the proneural cluster, and $\mathrm{E}(\mathrm{spl} / \mathrm{m} 7$, in turn, acts to repress ac expression in all cells of the cluster except the SOP.

\section{Two distinct mechanisms of negative transcriptional regulation by $\mathrm{HLH}$ proteins}

The work presented here and in previous reports reveals two distinct mechanisms by which the HLH proteins $h$ and emc can negatively regulate the transcriptional activity of the same gene, ac (Fig. 7).

Here, we have described evidence that $h$ acts as a negative regulator of $a c$ by a mechanism of direct DNA binding and transcriptional repression (Fig. 7A). In contrast, previous studies have elucidated a very different mechanism of action for emc (Fig. 7B). The emc protein contains an HLH domain, but lacks the adjacent basic region that constitutes the DNA-binding domain of bHLH proteins (Ellis et al. 1990; Garrell and Modolell 1990). The ac and sc proteins can both form complexes with da that are capable of binding DNA and activating transcription (Cabrera and Alonso 1991; Van Doren et al. 1991, 1992). emc can act as a negative regulator of transcription by forming complexes with the ac, sc, and da proteins (P.A. Powell and J.W. Posakony, in prep.) that are inactive in DNA binding (Van Doren et al. 1991) and transcriptional activation (Van Doren et al. 1992). The ac gene itself is a direct target of activation by ac-sc-containing protein complexes (Van Doren et al. 1992; Martinez et al. 1993), and emc negatively regulates ac expression by interfering with this auto- and cross-regulation (Fig. 7B; Van Doren et al. 1992; Martinez et al. 1993). Thus, two HLH proteins, $h$ and emc, function in vivo as negative regulators of $a c$ transcription via distinct molecular mechanisms. Given that $a c$ itself encodes a bHLH transcriptional activator, it is apparent that the regulatory versatility of the HLH proteins is well illustrated by the process of adult sensory organ patterning in Drosophila.

\section{Materials and methods}

Drosophila stocks

Flies were raised on standard yeast/cornmeal/molasses/agar medium. Mutant strains are described in Lindsley and Zimm (1992).

\section{General molecular biology methods}

Standard techniques of molecular biology were performed as described (Ausubel et al. 1987; Sambrook et al. 1989).

\section{Protein expression and purification}

For the full-length GST-h fusion protein construct, a $h$ cDNA (Van Doren et al. 1991) was cut at the BstEII site immediately 3' of the start codon, and the ends were blunted with Klenow DNA polymerase. This DNA was then digested with Sall and subcloned into EcoRI-cut, Klenow-blunted, and SalI-cut pGEX KG (Guan and Dixon 1991), creating pGEX-h. The predicted fusion protein from this construct contains all of the h protein except for the initiator methionine. For the truncated GST-htr fusion protein, a BamHI-XmnI fragment from pGEX-h was subcloned into HindIII-cut, Klenow-blunted, and BamHI-cut pGEX KG, creating pGEX-htr. The predicted fusion protein produced from this construct contains amino acids 2-110 of h (of 337 amino acids total) and also has 5 additional amino acids added to the carboxyl terminus. For the truncated GST-m7tr fusion protein, an MscI-Ncol fragment of $E(s p l) m 7$ genomic DNA was subcloned into Xbal-cut, Klenow-blunted, and NcoI-cut pGEX KG, creating $\mathrm{pGEX}-\mathrm{m} 7 \mathrm{Nco}$. The predicted fusion protein from this construct contains amino acids 2-127 of E/spl)m7 (of 186 amino acids totall, and 10 additional amino acids are added to the carboxyl terminus.

For fusion protein production, the above expression constructs were transformed into BL21 DE3 competent cells. For each construct, $500 \mathrm{ml}$ of Luria broth plus $100 \mu \mathrm{g} / \mathrm{ml}$ of ampicillin (LB AMP) was inoculated with a $10-\mathrm{ml}$ culture that had grown overnight in LB AMP at $37^{\circ} \mathrm{C}$, and was incubated at $37^{\circ} \mathrm{C}$ to an optical density at $600 \mathrm{~nm}\left(\mathrm{OD}_{600}\right)$ of $\sim 0.2$. The culture was transferred to $30^{\circ} \mathrm{C}$ until it reached an $\mathrm{OD}_{600}$ of $0.6-0.7$, isopropyl- $\beta$-D-thiogalactopyranoside (IPTG) was added to a final concentration of $0.4 \mathrm{~mm}$, and the culture was incubated $1 \mathrm{hr}$ at $30^{\circ} \mathrm{C}$. Cells were harvested by centrifugation at $4000 \mathrm{~g}$ for $5 \mathrm{~min}$ and washed in $\sim 150 \mathrm{ml}$ of cold phosphate-buffered saline (PBS). Cells were resuspended in $8 \mathrm{ml}$ of ice-cold GST sonication buffer [GSB: $25 \mathrm{mM} \mathrm{K}{ }^{+}$HEPES at $\mathrm{pH} 7.5,0.3 \mathrm{M} \mathrm{KCl}, 1 \mathrm{~mm}$ 
ethylenediaminetetracetic acid (EDTA), $0.1 \%$ Nonidet P40 (NP40 ), $10 \%$ glycerol, $1 \mathrm{~mm}$ dithiothreitol (DTT), $1 \mathrm{~mm}$ phenylmethylsulfonyl floride (PMSF), $2 \mu \mathrm{g} / \mathrm{ml}$ of aprotinin, $2 \mu \mathrm{g} / \mathrm{ml}$ of leupeptin, $1 \mu \mathrm{g} / \mathrm{ml}$ of pepstatin A], and $5 \mathrm{mg}$ of lysozyme was added followed by a $15-\mathrm{min}$ incubation on ice. Cells were then sonicated on ice (5 $\times 30 \mathrm{sec}$ on $/ 30 \mathrm{sec}$ off) at $60 \%$ power using a Fisher sonicator (Dismembrator model 300 ). The lysate was clarified by centrifugation at $20,000 \mathrm{~g}$ for $10 \mathrm{~min}$, and the supernatant was incubated for $30 \mathrm{~min}$ at $4^{\circ} \mathrm{C}$ with $1 \mathrm{ml}$ packed volume of glutathione-Sepharose beads (Pharmacia), pre-equilibrated with GSB. The beads were collected by centrifugation at $1000 \mathrm{~g}$ for $30 \mathrm{sec}$ and washed six times in $10 \mathrm{ml}$ of GST wash buffer $(\mathrm{GWB}=\mathrm{GSB}$ without glycerol), including a 5-min incubation with agitation during the second and third washes. Protein was eluted by washing the beads three times in a total of 2 $\mathrm{ml}$ of GWB plus $50 \mathrm{~mm}$ glutathione (reduced form), incubating 5-10 min at $4^{\circ} \mathrm{C}$ during each elution. The eluate was dialyzed overnight against $3 \times 2$ liters of $1.1 \times$ dialysis buffer $(1.1 \times \mathrm{DB}$ : $27.5 \mathrm{mM} \mathrm{K}^{+}$HEPES at $\mathrm{pH} 7.5,55 \mathrm{~mm} \mathrm{KCl}, 0.11 \mathrm{mM}$ EDTA, $0.11 \% \mathrm{NP}-40$ ), with $0.2 \mathrm{mM}$ PMSF included in the first 2 liters. The dialyzed protein was recovered, one-tenth volume of glycerol was added, and aliquots were frozen in liquid nitrogen and stored at $-80^{\circ} \mathrm{C}$. The yield of full-length fusion protein was estimated by separating samples on polyacrylamide gels and comparing the Coomassie staining intensity of the appropriate band to known amounts of bovine serum albumin standard.

For the restriction fragment precipitation experiments, fusion protein production differed from the above protocol in that protein induction was done at $37^{\circ} \mathrm{C}$, cells were lysed by freeze/ thawing in the presence of $1 \%$ Triton X-100, $5 \mathrm{mM} \mathrm{MgCl}_{2}$ was included in the buffers, the $\mathrm{KCl}$ concentration was only $20 \mathrm{mM}$ during lysis, only the HEPES, DTT, and $10 \mathrm{~mm}$ glutathione were present during the elution, and NP-40 was not used in any step. For the DMS protection experiments, the purification protocol differed from the one detailed above in that $12.5 \mathrm{mM} \mathrm{MgCl}_{2}$ was present during sonication, only the HEPES, DTT, and $10 \mathrm{~mm}$ glutathione were present during the elution, $5 \mathrm{mM} \mathrm{MgCl}_{2}$ was present in the dialysis buffer, and NP-40 was not present in the dialysis buffer.

For in vitro synthesis of htr protein with wheat germ translation lysates, the $h$ cDNA was cut with $X m n I$, and RNA and protein were synthesized as described previously (Van Doren et al. 1991).

\section{Precipitation of labeled restriction fragments with $G-h$ tr}

A 0.9-kb EcoRI-Eco47III fragment of ac genomic DNA, including $874 \mathrm{bp} 5^{\prime}$ of the start of transcription, was subcloned in to $\mathrm{pKS1}^{+}$(Van Doren et al. 1992). The entire fragment was liberated from this subclone by digestion with PstI and XbaI, gel purified, and digested with $\mathrm{HaeIII}$. The resulting fragments were dephosphorylated with calf intestinal alkaline phosphatase and then radioactively labeled with $\left[\gamma^{-}{ }^{32} \mathrm{P}\right] \mathrm{ATP}$ and T4 polynucleotide kinase. The fragments were incubated in a $15-\mu 1$ reaction with $1 \mu \mathrm{g}$ of GST-htr, $1 \mu \mathrm{g}$ of poly[d(I-C)], and reaction buffer containing $25 \mathrm{mM} \mathrm{K}^{+}$HEPES ( $\mathrm{pH} 7.5$ ), $50 \mathrm{mM} \mathrm{KCl}, 5 \mathrm{mM} \mathrm{MgCl}_{2}$, $1 \mathrm{mM}$ EDTA, and $1 \mathrm{mM}$ DTT. After a 30-min incubation at room temperature, $10 \mu l$ of packed volume of glutathione-sepharose beads (pre-equilibrated in reaction buffer) was added, followed by an additional 10-min incubation at room temperature. The reaction was chilled on ice, and the beads were washed quickly twice with $0.5 \mathrm{ml}$ of ice-cold reaction buffer. Complexes were eluted from the beads by washing twice with $50 \mu \mathrm{l}$ of $25 \mathrm{mM} \mathrm{K}^{+}$ HEPES ( $\mathrm{pH} 7.5$ ) plus $10 \mathrm{~mm}$ glutathione at room temperature. After elution, $5 \mu \mathrm{l}$ of $10 \%$ SDS was added to the eluate, which was then incubated for $5 \mathrm{~min}$ at $65^{\circ} \mathrm{C}$. The eluate was extracted with $300 \mu \mathrm{l}$ of phenol/chloroform $(1: 1)$, and the nucleic acid was precipitated by addition of $2 \mu \mathrm{g}$ of yeast tRNA, $10 \mu \mathrm{l}$ of $3 \mathrm{M}$ sodium acetate, and $250 \mu \mathrm{l}$ of ethanol. The pellet was dissolved and electrophoresed on an $8 \%$ polyacrylamide/Tris-borateEDTA (TBE) gel along with a sample of $10 \%$ of the input (untreated) labeled HaeIII fragments.

\section{Methylation protection assays}

The 110-bp HaeIII fragment from the 0.9-kb ac upstream fragment was subcloned into the $S m a \mathrm{I}$ site of $\mathrm{pKS1}^{+}$. An EcoRI$\mathrm{XbaI}$ fragment containing the entire 110 -bp sequence was excised, as was an AvaII-SacI fragment that contains approximately one-half of this sequence. When these fragments are radioactively labeled with $\left[\alpha^{32} \mathrm{P}\right] \mathrm{dCTP}$ and Klenow DNA polymerase, only one of the two DNA strands incorporates the label, and the two fragments differ as to which strand becomes labeled. htr was cleaved from GST-htr by incubation of $14 \mu \mathrm{g}$ of GST-htr with 10 units of human thrombin (Sigma) in the presence of $2.5 \mathrm{mM} \mathrm{CaCl}_{2}$ for $30 \mathrm{~min}$ at room temperature. Cleaved htr $(1 \mu \mathrm{g})$ was combined with $200,000 \mathrm{cpm}$ of labeled DNA and $6 \mu \mathrm{g}$ of poly[d(I-C)] in a volume of $60 \mu \mathrm{l}$, including $25 \mathrm{mM} \mathrm{K}^{+}$ HEPES (pH 7.5), $50 \mathrm{~mm} \mathrm{KCl}, 5 \mathrm{~mm} \mathrm{MgCl} 2,0.1 \mathrm{~mm}$ EDTA and $6.7 \%$ glycerol. After $20 \mathrm{~min}$ at room temperature, the reactions were chilled on ice, and $1 \mu \mathrm{l}$ of DMS was added, followed by an additional 1-min incubation on ice. The reactions were centrifuged for $10 \mathrm{sec}$ and $1 \mu \mathrm{l}$ of $14.4 \mathrm{M} \beta$-mercaptoethanol was added to $55 \mu \mathrm{l}$ of the supernatant, which was immediately loaded onto a $4 \%$ polyacrylamide/ $0.5 \times$ TBE gel and electrophoresed at 7.5 $\mathrm{V} / \mathrm{cm}$ for $2.5 \mathrm{hr}$. The gel was exposed to film, and regions of the gel corresponding to free probe and probe complexed with htr were excised and processed for piperidine cleavage of methylated bases and gel electrophoresis as described (Ausubel et al. 1987).

\section{Random binding site selection}

A double-stranded random oligonucleotide pool was generated by annealing the random-1 oligonucleotide, 5'-GTAAAACGACGGCCAGTGAAGCTTGAATTCNNNNNNNNNNNNNNGGATCCTCTAGACATGGTCATAGCTGTTTCC, with the M13 reverse sequencing primer, 5'-GGAAACAGCTATGACCATG, and extending with Klenow DNA polymerase at $50^{\circ} \mathrm{C}$. Glutathione-Sepharose beads containing bound GST-htr protein were prepared as described above, but the protein was not eluted. Instead, $200 \mu \mathrm{l}$ of packed bead volume was used to make a column, which was blocked with $250 \mu \mathrm{g}$ of sheared salmon sperm DNA and $20 \mu \mathrm{g}$ of poly[d(A-T)] in $150 \mu$ l of HEGN $100 / 25$ $\mathrm{mM} \mathrm{K}{ }^{+}$HEPES at $\mathrm{pH} 7.5,0.1 \mathrm{~mm}$ EDTA, $10 \%$ glycerol, $0.1 \%$ $\mathrm{NP}-40,100 \mathrm{mM} \mathrm{KCl}$; in subsequent steps, various $\mathrm{KCl}$ concentrations were employed, as indicated by the number, in millimolarity, following HEGN). The column was washed $2 \times$ in HEGN $500,2 \times$ in HEGN 1000 , and $3 \times$ in HEGN $100(0.5-\mathrm{ml}$ washes), and loaded with $2 \mu \mathrm{g}$ of double-stranded random- 1,5 $\mu \mathrm{g}$ of poly[d $(\mathrm{A}-\mathrm{T})]$, and $\sim 10^{5} \mathrm{cpm}$ radiolabeled $a c \mathrm{~h} / \mathrm{E}-1$ oligonucleotide probe (below) in a volume of $50 \mu \mathrm{l}$ and final buffer concentration of $1 \times \mathrm{DB}$. The labeled $a c \mathrm{~h} / \mathrm{E}-1$ probe was used to monitor column performance but does not contain the restriction sites necessary for the subsequent cloning steps. After incubating for $40 \mathrm{~min}$ at room temperature, the column was washed with 10 column volumes of HEGN 400 and 10 column volumes of HEGN 500, and was then eluted with $250-\mu$ fractions of HEGN 800 . The second HEGN 800 fraction contained a majority of the input $a c \mathrm{~h} / \mathrm{E}-1$ oligonucleotide and was precipitated by addition of $144 \mu \mathrm{l}$ of $\mathrm{dH}_{2} 0,2 \mu \mathrm{I}$ of $1 \mathrm{M} \mathrm{MgCl}_{2}, 4 \mu \mathrm{g}$ of yeast tRNA, and $1 \mathrm{ml}$ of ethanol. After recovery, the eluted 
DNA was used to load a second GST-htr column as above, which was washed with 10 column volumes of HEGN 400, 5 column volumes of HEGN 500 , and eluted with $250-\mu$ l fractions of HEGN 800 . Again, the second HEGN 800 fraction contained the majority of the $a c \mathrm{~h} / \mathrm{E}-1$ oligonucleotide and was precipitated as above. By taking a single column fraction in each of the two rounds of purification, $38 \%$ of the input $a c \mathrm{~h} / \mathrm{E}-\mathrm{l}$ oligonucleotide was recovered. The eluted DNA was then digested with HindIII and $\mathrm{XbaI}$, and subcloned into $\mathrm{pKS1}^{+}$. Plasmids with correct random-1 insertions were then sequenced as doublestranded DNA. In the aligned sequences (Fig. 2A), bases derived from nonrandom portions of the random-1 oligonucleotide were not included as part of the final analysis.

\section{EMSA}

An $a c$ h/E-l probe was generated by annealing the following oligonucleotides: 5'-GGCAGCCGGCACGCGACAGGG and 5 '-CCCCCTGTCGCGTGCCGGCTG, where the region protected from methylation by GST-htr is indicated in bold. The resulting double-stranded oligonucleotide was radiolabeled by extension of the overhanging ends with $\left[\alpha^{-32} \mathrm{P}\right] \mathrm{dCTP}$ and Klenow DNA polymerase. Mutant competitor probes were generated by annealing oligonucleotides that are identical to the ones above except for the single base pair changes indicated in Figure 2B. The DNA-binding reactions contained, in addition to protein ( 40 fmoles for the competition assays), 40 fmoles of labeled $a c \mathrm{~h} / \mathrm{E}-\mathrm{l}$ probe, $100 \mathrm{ng}$ of poly|d(A-T)], $7 \%$ glycerol, and $1 \times \mathrm{DB}$ (final concentration) in a volume of $10 \mu \mathrm{l}$. After a 20-min incubation at room temperature, $8 \mu$ l of each reaction was loaded on a $4 \%$ polyacrylamide/ $0.5 \times$ TBE gel and elecrophoresed at $7.5 \mathrm{~V} / \mathrm{cm}$ for $2.5 \mathrm{hr}$. The gel was then dried and exposed to film. For the oligomerization experiment (Fig. 2C), the proteins were preincubated in $1 \times \mathrm{DB}$ plus $10 \%$ glycerol in a volume of $7 \mu \mathrm{l}$ for $1 \mathrm{hr}$ at room temperature prior to the addition of DNAs and the 20-min binding incubation.

\section{Cloning of the $\mathrm{D}$. virilis ac gene}

A $D$. virilis genomic DNA library, a kind gift of Ron Blackman (University of Illinois, Urbana), was screened by low-stringency hybridization with a probe derived from a portion of the $D$. melanogaster ac coding sequence that lacked the region encoding the glutamine repeats (J. Esnayra, unpubl.). DNA from a bacteriophage recovered in this screen was subcloned and identified as containing the $D$. virilis ac homolog by comparison of coding region sequence data to the $D$. melanogaster ac sequence.

\section{Cotransfection assays}

Drosophila S2 cells were grown in Schneider cell medium (GIBCO) supplemented with $12.5 \%$ fetal calf serum (Gemini), penicillin, and streptomycin.

The ac h/E-1 wild-type and mutant target promoters were generated by ligating annealed, double-stranded $a c \mathrm{~h} / \mathrm{E}-1$ oligonucleotides or mutant $\mathrm{m} 2$ oligonucleotides with T4 DNA ligase, and gel purifying products containing four copies; the ends of these fragments were then blunted with Klenow DNA polymerase, and they were subcloned into SmaI-digested $\mathrm{pKSI}^{+}$. After the correct sequence and orientation were verified, these fragments were cloned into pD86 (England et al. 1990) by use of $P s t \mathrm{I}$ and $\mathrm{XbaI}$. Expression constructs were based on the parental vector pAct5CPPA (Han et al. 1989), which expresses inserted DNA by use of the Drosophila actin 5C promoter. For $h$, a $h$ cDNA was digested with $\mathrm{XbaI}$, blunted with Klenow DNA polymerase, and digested with Sall. This fragment was subcloned into $\mathrm{pKS1}{ }^{+}$digested with SmaI and SaII, creating pKSh. pKSh was digested with XhoI, partially extended with Klenow DNA polymerase adding only dCTP and dTTP, and digested with SacI. This fragment was cloned into pAct5CPPA that had been digested with BgIII, partially extended with Klenow DNA polymerase by use of only dATP and dGTP, and digested with SacI, creating pACh; this construct is expected to express fulllength h protein. For $E(s p l) m 7$, an $X m n I-B g I I I$ fragment of $E(s$ pl/m 7 genomic DNA was cloned into pAct5CPPA that had been digested with BamHI, blunted with Klenow DNA polymerase, and digested with Bg/II, creating pACm7; this construct is expected to express full-length $\mathrm{E}(\mathrm{spl}) \mathrm{m} 7$ protein.

Transfections, $\beta$-galactosidase assays, and CAT assays were carried out as described (Gorman 1985; Van Doren et al. 1992), except that $10^{6} \mathrm{~S} 2$ cells were plated the day before transfection, and $0.2 \mu \mathrm{g}$ of wild-type or mutant $a c \mathrm{~h} / \mathrm{E}-1-\mathrm{ADH}-\mathrm{CAT}$ DNA, $0.33 \mu \mathrm{g}$ of pACh or pACm7 DNA, and a total of $3 \mu \mathrm{g}$ of pAct5CPPA DNA (parental plus expression constructs) were used per plate of cells.

\section{Construction, transformation, and analysis of ac transgenes}

The construction and germ-line transformation of the wild-type $a c$ transgene, as well as the generation of many of the plasmids used, has been described previously (Van Doren et al. 1992). PCR was used to generate a NaeI-BamHI fragment of the $a c$ upstream region that contained a mutated $a c \mathrm{~h} / \mathrm{E}-\mathrm{l}$ site (CACGCG $\rightarrow$ CCCTCT). The sequence of the entire fragment was verified and used to replace the wild-type NaeI-BamHI fragment from pT5-2.2. The 2.2-kb EcoRI fragment from this h/E-1 mutant version of pT5-2.2 was then subcloned into pCaSpeR (Pirrotta 1988) in the same orientation as pCSPT52.2. Transgenic flies containing this construct were then generated by standard $P$ element-mediated germ-line transformation techniques (Rubin and Spradling 1982), using $w^{1118}$ as the recipient strain.

Adult tissue was dissected and mounted for light microscopy in Hoyer's medium.

\section{Acknowledgments}

We thank Ron Blackman for providing the $D$. virilis genomic DNA library, Andy Singson, Bruce England, Dave Kosman, and Steve Small for providing plasmid DNAs, Scott Erdman and Ken Burtis for providing the random binding site selection protocol prior to publication, Ingrid Ghattas for suggestions on the methylation protection assay, Leslie Kerrigan for suggestions on protein purification, Eben Masari for construction of pGEX-htr, Dahna Pasternak and Pam Nero for technical assistance in cloning the $D$, virilis ac homolog, and Geoff Cereghino, Rick Firtel, Josh Kavaler, Mike Levine, Kees Murre, and Andy Singson for critical reading of the manuscript. We also thank Michael Caudy for discussions and exchange of information prior to publication. This work was supported by National Institutes of Health (NIH) predoctoral training grants and by $\mathrm{NIH}$ grant GM46993.

The publication costs of this article were defrayed in part by payment of page charges. This article must therefore be hereby marked "advertisement" in accordance with 18 USC section 1734 solely to indicate this fact.

\section{References}

Akazawa, C., Y. Sasai, S. Nakanishi, and R. Kageyama. 1992. Molecular characterization of a rat negative regulator with a 
basic helix-loop-helix structure predominantly expressed in the developing nervous system. $J$. Biol. Chem. 267: 2187921885.

Ausubel, F.M., R. Brent, R.E. Kingston, D.D. Moore, J.G. Seidman, J.A. Smith, and K. Struhl. 1987. Current protocols in molecular biology. Greene/John Wiley, New York.

Bang, A., V. Hartenstein, and J.W. Posakony. 1991. Hairless is required for the development of adult sensory organ precursor cells in Drosophila. Development 111: 89-104.

Bier, E., H. Vaessin, S. Younger-Shepherd, L.Y. Jan, and Y.N. Jan. 1992. deadpan, an essential pan-neural gene in Drosophila, encodes a helix-loop-helix protein similar to the hairy gene product. Genes \& Dev. 6: 2137-2151.

Botas, J., J. Moscoso del Prado, and A. García-Bellido. 1982. Gene-dose titration analysis in the search of trans-regulatory genes in Drosophila. EMBO I. 1: 307-310.

Cabrera, C.V. and M.C. Alonso. 1991. Transcriptional activation by heterodimers of the achaete-scute and daughterless gene products of Drosophila. EMBO J. 10: 2965-2973.

Carroll, S.B. and M.P. Scott. 1986. Zygotically active genes that affect the spatial expression of the fushi tarazu segmentation gene during early Drosophila embryogenesis. Cell 45: $113-126$.

Caudy, M., H. Vässin, M. Brand, R. Tuma, L.Y. Jan, and Y.N. Jan. 1988. daughterless, a Drosophila gene essential for both neurogenesis and sex determination, has sequence similarities to myc and the achaete-scute complex. Cell 55: 10611067.

Cronmiller, C. and C. Cummings. 1993. The daughterless gene product in Drosophila is a nuclear protein that is broadly expressed throughout the organism during development. Mech. Dev. 42: 159-169.

Cronmiller, C., P. Schedl, and T.W. Cline. 1988. Molecular characterization of daughterless, a Drosophila sex determination gene with multiple roles in development. Genes \& Dev. 2: 1666-1676.

Cubas, P. and J. Modolell. 1992. The extramacrochaetae gene provides information for sensory organ patterning. $E M B O J$. 11: 3385-3393.

Cubas, P., J.-F. de Celis, S. Campuzano, and J. Modolell. 1991. Proneural clusters of achaete-scute expression and the generation of sensory organs in the Drosophila imaginal wing disc. Genes \& Dev. 5: 996-1008.

Dang, C.V., C. Dolde, M.L. Gillison, and G.J. Kato. 1992. Discrimination between related DNA sites by a single amino acid residue of Myc-related basic-helix-loop-helix proteins. Proc. Natl. Acad. Sci. 89: 599-602.

Delidakis, C. and S. Artavanis-Tsakonas. 1992. The Enhancer of split [E(spl)] locus of Drosophila encodes seven independent helix-loop-helix proteins. Proc. Natl. Acad. Sci. 89: 87318735.

Ellis, H.M., D.R. Spann, and J.W. Posakony. 1990. extramacrochaetae, a negative regulator of sensory organ development in Drosophila, defines a new class of helix-loop-helix proteins. Cell 61: 27-38.

England, B.P., U. Heberlein, and R. Tjian. 1990. Purified Drosophila transcription factor, Adh distal factor-1 (Adf-1), binds to sites in several Drosophila promoters and activates transcription. J. Biol. Chem. 265: 5086-5094.

Feder, J.N., L.Y. Jan, and Y.N. Jan. 1993. A rat gene with sequence homology to the Drosophila gene hairy is rapidly induced by growth factors known to influence neuronal differentiation. Mol. Cell. Biol. 13: 105-113.

Ferre-D'Amare, A.R., G.C. Prendergast, E.B. Ziff, and S.K. Burley. 1993. Recognition by Max of its cognate DNA through a dimeric b/HLH/Z domain. Science 363: 38-44.
Garrell, J. and J. Modolell. 1990. The Drosophila extramacrochaetae locus, an antagonist of proneural genes that, like these genes, encodes a helix-loop-helix protein. Cell 61: 39 48.

Gorman, C. 1985. High efficiency gene transfer into mammalian cells. In DNA cloning: A practical approach (ed. D.M. Glover), pp. 143-190. IRL Press, Oxford, England, UK.

Guan, K.L. and J.E. Dixon. 1991. Eukaryotic proteins expressed in Escherichia coli: An improved thrombin cleavage and purification procedure of fusion proteins with glutathione $\mathrm{S}$ transferase. Anal. Biochem. 192: 262-267.

Han, K., M.S. Levine, and J.L. Manley. 1989. Synergistic activation and repression of transcription by Drosophila homeobox proteins. Cell 56: 573-583.

Hartenstein, V. and J.W. Posakony, 1989. Development of adult sensilla on the wing and notum of Drosophila melanogaster. Development 107: 389-405.

- 1990. A dual function of the Notch gene in Drosophila sensillum development. Dev. Biol. 142: 13-30.

Heitzler, P. and P. Simpson. 1991. The choice of cell fate in the epidermis of Drosophila. Cell 64: 1083-1092.

. 1993. Altered epidermal growth factor-like sequences provide evidence for a role of Notch as a receptor in cell fate decisions. Development 117: 1113-1123.

Hinz, U., B. Giebel, and J.A. Campos-Ortega. 1994. The basichelix-loop-helix domain of Drosophila lethal of scute protein is sufficient for proneural function and activates neurogenic genes. Cell 76: 77-87.

Howard, K. and P. Ingham. 1986. Regulatory interactions between the segmentation genes fushi tarazu, hairy, and engrailed in the Drosophila blastoderm. Cell 44: 949-957.

Huang, F., C. Dambly-Chaudière, and A. Ghysen. 1991. The emergence of sense organs in the wing disc of Drosophila. Development 111: 1087-1095.

Ish-Horowicz, D. and S.M. Pinchin. 1987. Pattern abnormalities induced by ectopic expression of the Drosophila gene hairy are associated with the repression of $f t z$ transcription. Cell 51: 405-415.

Ishibashi, M., Y. Sasai, S. Nakanishi, and R. Kageyama. 1993. Molecular characterization of HES-2, a mammalian helixloop-helix factor structurally related to Drosophila hairy and Enhancer of split. Eur. I. Biochem. 215: 645-652.

Ishibashi, M., K. Moriyoshi, Y. Sasai, K. Shiota, S. Nakanishi, and R. Kageyama. 1994. Persistent expression of helix-loophelix factor HES-1 prevents mammalian neural differentiation in the central nervous system. EMBO J. 13: 1799-1805.

Klämbt, C., E. Knust, K. Tietze, and J. Campos-Ortega. 1989. Closely related transcripts encoded by the neurogenic gene complex Enhancer of split of Drosophila melanogaster. EMBO I. 8: 203-210.

Knust, E., K.A. Bremer, H. Vässin, A. Ziemer, U. Tepass, and J.A. Campos-Ortega. 1987. The Enhancer of split locus and neurogenesis in Drosophila melanogaster. Dev. Biol. 122: 262-273.

Knust, E., H. Schrons, F. Grawe, and J.A. Campos-Ortega. 1992. Seven genes of the Enhancer of split complex of Drosophila melanogaster encode helix-loop-helix proteins. Genetics 132: $505-518$.

Kramatschek, B. and J.A. Campos-Ortega. 1994. Neuroectodermal transcription of the Drosophila neurogenic genes $E$ (spl) and $H L H-m 5$ is regulated by proneural genes. Development 120: $815-826$.

Lindsley, D.L. and G.G. Zimm. 1992. The genome of Drosophila melanogaster. Academic Press, San Diego, CA.

Martinez, C. and J. Modolell. 1991. Cross-regulatory interactions between the proneural achaete and scute genes of 
Drosophila. Science 251: 1485-1487.

Martinez, C., J. Modolell, and J. Garrell. 1993. Regulation of the proneural gene achaete by helix-loop-helix proteins. Mol. Cell. Biol. 13: 3514-3521.

Moscoso del Prado, J. and A. García-Bellido. 1984. Genetic regulation of the Achaete-scute complex of Drosophila melanogaster. Wilhelm Roux's Arch. Dev. Bio. 193: 242-245.

Murre, C., P. Schonleber McCaw, and D. Baltimore. 1989. A new DNA binding and dimerization motif in immunoglobulin enhancer binding, daughterless, myoD, and myc proteins. Cell 56: 777-783.

Nüsslein-Volhard, C. and E. Wieschaus. 1980. Mutations affecting segment number and polarity in Drosophila. Nature 287: 795-801.

Ohsako, S., J. Hyer, G. Pangiban, I. Oliver, and M. Caudy. 1994. hairy functions as a DNA binding HLH repressor of Droso. phila sensory organ formation. Genes \& Dev. (this issue).

Orenic, T.V., L.I. Held, S.W. Paddock, and S.B. Carroll. 1993. The spatial organization of epidermal structures: hairy establishes the geometrical pattern of Drosophila leg bristles by delimiting the domains of achaete expression. Development 118: 9-20.

Parks, A.L. and M.A. Muskavitch. 1993. Delta function is required for bristle organ determination and morphogenesis in Drosophila. Dev. Biol. 157: 484-496.

Pirrotta, V. 1988. Vectors for P-mediated transformation in Drosophila. In Vectors: A survey of molecular cloning vectors and their uses (ed. R.L. Rodriguez and D.T. Denhardt), pp. 437-456. Butterworth, Stoneham, MA.

Ramain, P., P. Heitzler, M. Haenlin, and P. Simpson. 1993. pannier, a negative regulator of achaete and scute in Drosophila, encodes a zinc finger protein with homology to the vertebrate transcription factor GATA-1. Development 119: 12771291.

Rodriguez, I., R. Hernandez, J. Modolell, and M. Ruiz-Gomez. 1990. Competence to develop sensory organs is temporally and spatially regulated in Drosophila epidermal primordia. EMBO I. 9: 3583-3592.

Rubin, G.M. and A.C. Spradling. 1982. Genetic transformation of Drosophila with transposable element vectors. Science 218: 348-353.

Rushlow, C.A., A. Hogan, S.A. Pinchin, K.M. Howe, M. Lardelli, and D. Ish-Horowicz. 1989. The Drosophila hairy protein acts in both segmentation and bristle patterning and shows homology to N-myc. EMBO J. 8: 3095-3103.

Sambrook, J., E.F. Fritsch, and T. Maniatis. 1989. Molecular cloning; A laboratory manual. Cold Spring Harbor Laboratory Press, Cold Spring Harbor, New York.

Sasai, Y., R. Kageyama, Y. Tagawa, R. Shigemoto, and S. Nakanishi. 1992. Two mammalian helix-loop-helix factors stnucturally related to Drosophila hairy and Enhancer of split. Genes \& Dev. 6: 2620-2634.

Schweisguth, F. and J.W. Posakony. 1992. Suppressor of Hairless, the Drosophila homolog of the mouse recombination signal-binding protein gene, controls sensory organ cell fates. Cell 69: 1199-1212.

Singson, A., M.W. Leviten, A.G. Bang, X.H. Hua, and J.W. Posakony. 1994. Direct downstream targets of proneural activators in the imaginal disc include genes involved in lateral inhibitory signaling. Genes \& Dev. 8: 2058-2071.

Skeath, J.B. and S.B. Carroll. 1991. Regulation of achaete-scute gene expression and sensory organ pattern formation in the Drosophila wing. Genes \& Dev. 5: 984-995.

- 1992. Regulation of proneural gene expression and cell fate during neuroblast segregation in the Drosophila em. bryo. Development 114: 939-946.
Sturtevant, A.H. 1970. Studies on the bristle pattern of Drosophila. Dev. Biol. 21: 48-61.

Takebayashi, K., Y. Sasai, Y. Sakai, T. Watanabe, S. Nakanishi, and R. Kageyama. 1994. Structure, chromosomal locus, and promoter analysis of the gene encoding the mouse helixloop-helix factor HES-1. Negative autoregulation through the multiple $\mathrm{N}$ box elements. I. Biol. Chem. 269: 51505156.

Tietze, K., N. Oellers, and E. Knust. 1992. Enhancer of split ${ }^{D}$, a dominant mutation of Drosophila, and its use in the study of functional domains of a helix-loop-helix protein. Proc. Natl. Acad. Sci. 89: 6152-6156.

Van Doren, M., H.M. Ellis, and J.W. Posakony. 1991. The Drosophila extramacrochaetae protein antagonizes sequence-specific DNA binding by daughterless/achaete-scute protein complexes. Development 113: 245-255.

Van Doren, M., P.A. Powell, D. Pasternak, A. Singson, and J.W. Posakony. 1992. Spatial regulation of proneural gene activity: Auto- and cross-activation of achaete is antagonized by extramacrochaetae. Genes \& Dev. 6: 2592-2605.

Villares, R. and C.V. Cabrera. 1987. The achaete-scute gene complex of $\mathrm{D}$. melanogaster: conserved domains in a subset of genes required for neurogenesis and their homology to myc. Cell 50: 415-424.

Wainwright, S.M. and D. Ish-Horowicz. 1992. Point mutations in the Drosophila hairy gene demonstrate in vivo requirements for basic, helix-loop-helix, and WRPW domains. Mol. Cell. Biol. 12: 2475-2483.

Younger-Shepherd, S., H. Vaessin, E. Bier, L.Y. Jan, and Y.N. Jan. 1992. deadpan, an essential pan-neural gene encoding an HLH protein, acts as a denominator in Drosophila sex determination. Cell 70: 911-922. 


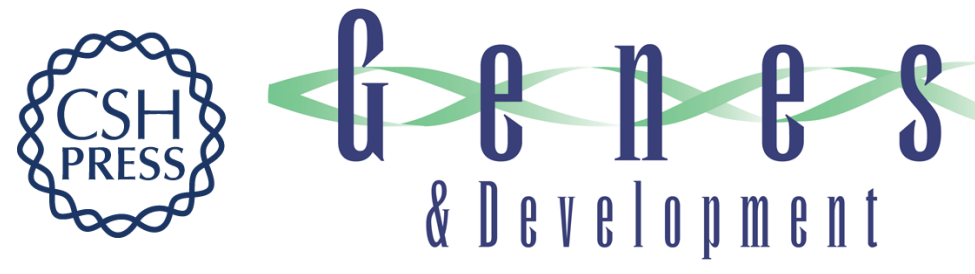

\section{Negative regulation of proneural gene activity: hairy is a direct transcriptional repressor of achaete.}

M Van Doren, A M Bailey, J Esnayra, et al.

Genes Dev. 1994, 8:

Access the most recent version at doi:10.1101/gad.8.22.2729

References This article cites 58 articles, 28 of which can be accessed free at:

http://genesdev.cshlp.org/content/8/22/2729.full.html\#ref-list-1

License

Email Alerting

Service

Receive free email alerts when new articles cite this article - sign up in the box at the top right corner of the article or click here.

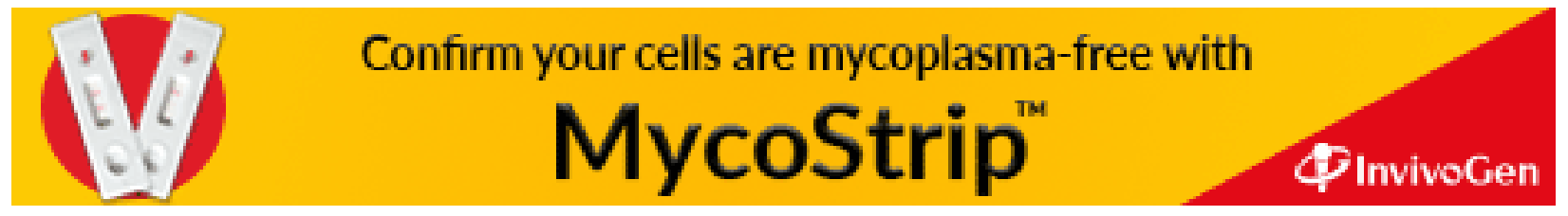

